\title{
NEW TAXA OF LAPAROCERUS SCHÖNHERR, 1834 FROM MADEIRA AND PORTO SANTO, WITH A KEY TO THE SPECIES OF THE MADEIRAN ARCHIPELAGO (COLEOPTERA, CURCULIONIDAE, ENTIMINAE)
}

\author{
A. Machado*
}

\begin{abstract}
As part of a monographic study of the weevil genus Laparocerus Schönherr, 1834, which is very diverse in Macaronesia, this paper proposes some changes to the systematics of the genus and describes a number of new taxa from the archipelago of Madeira. Combining the morphological data with the molecular data presented in a previous contribution, the subgenera Laparocerus and Atlantis are redefined and three new subgenera are described: Atlantodes n. subgen., Pseudatlantis n. subgen. and Wollastonius $\mathbf{n}$. subgen. In addition, six new species from Madeira are described: L. madeirensis $\mathbf{n} . \mathbf{s p}$., L. hobbit n. sp., L. serrado n. sp., L. silvaticus n. sp., L. stuebeni n. sp. and L. prainha n. sp., as well as L. cryptus n. sp. from the Ponta de São Lourenço, Porto Santo and Deserta Grande. A key to all known Laparocerus from the archipelago of Madeira is provided.
\end{abstract}

Key words: Curculionidae, Entiminae, Laparocerus, Madeira, Porto Santo, new species, new subgenera.

\section{RESUMEN}

Nuevos taxa de Laparocerus Schönherr, 1834 de Madeira y Porto Santo, con una clave de identificación de las especies del archipiélago de Madeira (Coleoptera, Curculionidae, Entiminae)

Como parte de un estudio monográfico sobre los coleópteros del género Laparocerus Schönherr, 1834, el cual es extraordinariamente diverso en Macaronesia, este trabajo propone algunos cambios en su sistemática y describe algunos nuevos taxa del archipiélago de Madeira. Combinando los datos morfológicos con los moleculares, presentados en una contribución previa, se redefinen los subgéneros Laparocerus y Atlantis y se describen tres nuevos subgéneros: Atlantodes n. subgen., Pseudatlantis n. subgen. y Wollastonius n. subgen. Asimismo, se describen seis especie nuevas de Madeira: $L$. madeirensis n. sp., L. hobbit n. sp., L. serrado n. sp., L. silvaticus n. sp., L. stuebeni $\mathbf{n}$. sp. and L. prainha n. sp., así como L. cryptus n. sp. de Ponta de São Lourenço, Porto Santo y Deserta Grande. Se proporciona también una clave de identificación de todas las especies de Laparocerus del archipiélago de Madeira.

Palabras clave: Curculionidae, Entiminae, Laparocerus, Madeira, Porto Santo, nuevas especies, nuevos subgéneros.

\footnotetext{
* c/ Chopin 1, 38208 La Laguna, Tenerife, Canary Islands, Spain. E-mail: antonio.machado@telefonica.net
} 


\section{Introduction}

The genus Laparocerus was established by Schönherr in 1834 to harbour two species described by Boheman in the same work, based on material from "Lusitania", a patria that was later clarified as being the island of Madeira. Wollaston, who worked on the Madeiran archipelago fauna in detail $(1854,1857,1862,1871)$, added one more Laparocerus, four species of Omias, the monotypic genus Cyphoscelis Wollaston, 1854, and eighteen species of Atlantis Wollaston, 1854. All these species were ascribed to the genus Laparocerus by Lacordaire (1863), with Cyphoscelis and Atlantis as sections (subgenera) of it. He also created the group "Laparocerides" including several non-Macaronesian genera (Aomus, Elytrodon, Merimnetes, etc.).The related Madeiran genus Lichenophagus Wollaston, 1854, which was placed in another group, has been recently transferred to the Laparocerini Lacordaire, 1863 by Alonso-Zarazaga \& Lyal (1999).

Since the initial studies of Wollaston there have been few additions to the list of Madeiran species (Uyttenboogaart, 1940; Roudier, 1958, 1961, 1963), but the number of Laparocerus and Lichenophagus species increased considerably due to further studies by Wollaston and other authors mainly in the Canary Islands (with several subgenera being established). The presently known distribution of the genus Laparocerus covers the archipelagos of Madeira, Selvagens and the Canaries, with a single species in mainland Africa (West Morocco).

This paper is part of a comprehensive systematic revision of the genus Laparocerus. A study of the type material of all species names ascribed to the genus yielded 24 valid species for the Madeiran archipelago (Machado, 2006). Preliminary results from a molecular analysis (Machado et al., 2008) suggest that the Madeiran Laparocerus species form a monophyletic group but also that Lichenophagus fritillus Wollaston, 1854 from Porto Santo clusters within the Laparocerus clade. Consequently, Lichenophagus was restricted to Madeiran archipelago species and relegated in status to a subgenus of Laparocerus. Furthermore, Cyphoscelis Wollaston, 1854 was synonymised with the subgenus Laparocerus Schönherr, 1834. A few other changes in the systematics of the genus Laparocerus were suggested in Machado et al. (2008) but not implemented.

The purpose of the present contribution is to describe three new subgenera, seven new species of Laparocerus and to redefine the concept of the sub- genera Laparocerus and Atlantis according to the results of the previous phylogenetic analysis of the Madeiran clade based on molecular data.The systematic scheme here presented is morphologically and molecularly supported and constitutes, as any phylogeny, a mere hypothesis.

A first key to all species from Madeira and Porto Santo is herein provided. Laparocerus piceus Boheman, 1834, the fossil Laparocerus wollastoni Heer, 1857 and Laparocerus obesulus Desbrochers, 1903 are not included as they have already been established as nomina dubia and a synonym, respectively (Machado, 2006).

\section{Materials and methods}

This study is based on material collected by the author in the field and borrowed from different institutions and private collections. Unfortunately no specimens of Laparocerus (Lichenophagus) acuminatus (Wollaston, 1854) from Desertas were available for study, and its characters as used in the key were taken from the original description. Holotypes of the new species are deposited in the Natural History Museum of Santa Cruz de Tenerife, Spain.

The names of the collections from which specimens were studied are abbreviated as follows:

AAC: Agustín Aguiar Clavijo, private collection. La Laguna, Spain.

AMC: Antonio Machado Carrillo, private collection. La Laguna, Spain.

MNHN: Muséum National d'Histoire Naturelle. Paris, France. MNCN: Museo Nacional de Ciencias Naturales. Madrid, Spain. NHM: The Natural History Museum. London, United Kingdom. NMW: Naturhistorisches Museum Wien. Vienna, Austria. NRS: Naturhistoriska Riksmuseet. Stockholm, Sweden. PS: Peter Stüben, private collection. Mönchengladbach, Germany. SMNS: Staatliches Museum für Naturkunde, Stuttgart, Germany. TFMC: Museo de Ciencias Naturales. Santa Cruz de Tenerife, Spain.

ZMUH: Zoological Museum, University of Helsinki, Finland. ZMUL: Zoological Museum, University of Lund, Sweden.

Photographs were taken with a Nikon digital camera, and drawings were made using a camera lucida attached to a microscope. Measurements were taken with a micrometer fitted to the microscope. The length, width and height of specimens are abbreviated as L, W and $\mathrm{H}$, respectively, where length excludes that of the rostrum and was measured in dorsal view. Eye convexity is expressed as percentage of a theoretical regular ellipsoid or globe protruding from the profile of the head; thus a $50 \%$ convexity refers to a hemispherical eye, $10 \%$ 
Table 1.- Pairwise distances of mtDNA COII in species of subgenus Laparocerus. Data taken from Machado et al. (2008) supplemented with data for Laparocerus chaoensis Uyttenboogaart, 1940.

Tabla 1.- P-distancias del DNA de la citocromo oxidasa II mitocondrial en especies del subgénero Laparocerus tomadas de Machado et al. (2008) y complementadas con datos de Laparocerus chaoensis Uyttenboogaart, 1940.

\begin{tabular}{|c|c|c|c|c|c|c|c|c|}
\hline & \multicolumn{3}{|c|}{ Laparocerus chaoensis } & \multicolumn{2}{|c|}{ Laparocerus distortus } & \multirow{2}{*}{$\begin{array}{c}\text { L. morio } \\
\text { M: Encumeada }\end{array}$} & \multicolumn{2}{|c|}{ L. cryptus n. sp. } \\
\hline & Ilheu Chao & Bugio & Desembarc. & M: Caldeirão & M: Folhadal & & Porto Santo & Deserta Gr \\
\hline \multicolumn{9}{|l|}{ L. chaoensis chaoensis } \\
\hline Ilheu de Chão & - & & & & & & & \\
\hline Ilheu de Bugio & $3.3 \%$ & - & & & & & & \\
\hline \multicolumn{9}{|l|}{ L. chaoensis cevadae } \\
\hline Ilheu Desembarcadouro & $3.8 \%$ & $5.8 \%$ & - & & & & & \\
\hline \multicolumn{9}{|l|}{ L. distortus } \\
\hline Mad. Caldeirão Verde & $6.5 \%$ & $8.1 \%$ & $5.8 \%$ & - & & & & \\
\hline Mad. El Folhadal & $6.5 \%$ & $8.1 \%$ & $5.8 \%$ & $0.7 \%$ & - & & & \\
\hline \multicolumn{9}{|l|}{ L. morio (2 exx) } \\
\hline Mad. Encumeada & $9.7 \%$ & $10.8 \%$ & $8.6 \%$ & $5.9 \%$ & $6.3 \%$ & - & & \\
\hline \multicolumn{9}{|l|}{ L. cryptus n.sp. } \\
\hline Porto Santo & $12.7 \%$ & $13.9 \%$ & $11.5 \%$ & $9.4 \%$ & $9.5 \%$ & $11.0 \%$ & - & \\
\hline Deserta Grande & $13.5 \%$ & $15.2 \%$ & $12.7 \%$ & $10.3 \%$ & $10.7 \%$ & $12.2 \%$ & $2.6 \%$ & \\
\hline Mad. Ponta S. Lourenço & $13.6 \%$ & $15.2 \%$ & $12.3 \%$ & $10.4 \%$ & $10.7 \%$ & $12.0 \%$ & $3.3 \%$ & $3.1 \%$ \\
\hline
\end{tabular}

to a fairly flat one, and so forth. Abdominal transverse convexity is determined by dividing the maximum height between elytra and ventrites in lateral view by the maximum width of the elytra measured in dorsal view.

The term prorostrum (taken from Damoiseau, 1967) refers here to the anterior and dorsal portion of the rostrum, delimited by the line where the apical declivity usually starts just at the level of insertion of the antennae; the metarostrum is the posterior portion. Spermathecal terminology follows Thompson (1989).

In order to better support the systematic decisions, the present morphological study is here combined with the results of the molecular analysis of Machado et al. (2008), where mitochondrial DNA markers (fragments of cytochrome oxydase subunit II and of ribosomal $16 \mathrm{~S}$ subunit) were selected as they are standard markers used in many phylogenetic studies (Caterino et al., 2000).

Figure 1 shows the Madeiran clade of Laparocerus according to the Bayesian 50\% majority-rule consensus tree obtained from the analysis of mitochondrial cytochrome oxidase II and ribosomal $16 \mathrm{~S}$ rRNA gene sequence data (a combined dataset of 1023 bp) by Machado et al. (2008, fig. 1). The phylogenetic tree has been simplified by removing the Bayesian support values and most Canarian, Azorean and some redundant Madeiran terminals.
Subclades representing subgenera have been additionally marked and are consistent with a second tree obtained by these authors (op. cit. fig. 2) adding a fragment of the nuclear elongation factor 1-alpha gene for selected taxa.

The Bayesian supported phylogram of subgenus Laparocerus shown in figure 4 has been obtained by including specimens of $L$. chacoensis s.l. recently collected in the islets of Bugio, Ilheu do Desembarcadouro and Ilheu de Chão. Their Genbank accession numbers are FJ495251 (COII) + FJ495254 (16S rRNA), FJ495252 (COII) + FJ595255 (16S rRNA), and FJ495253 (COII) + FJ495256 (16S rRNA), respectively. Methodology followed was the same of Machado et al. (2008). Pair-wise distances of mtDNA COII shown in Table 1 where calculated with MEGA.

Full species names, with author and year, are provided in the key.

\section{Results}

Subgenus Laparocerus Schönherr, 1834

TYPE SPECIES: Laparocerus morio Boheman, 1834, by original designation.

The monotypic genus Cyphoscelis Wollaston, 1854 , erected for $C$. distorta, was treated by Lacordaire (1863) as a subgenus of Laparocerus. 


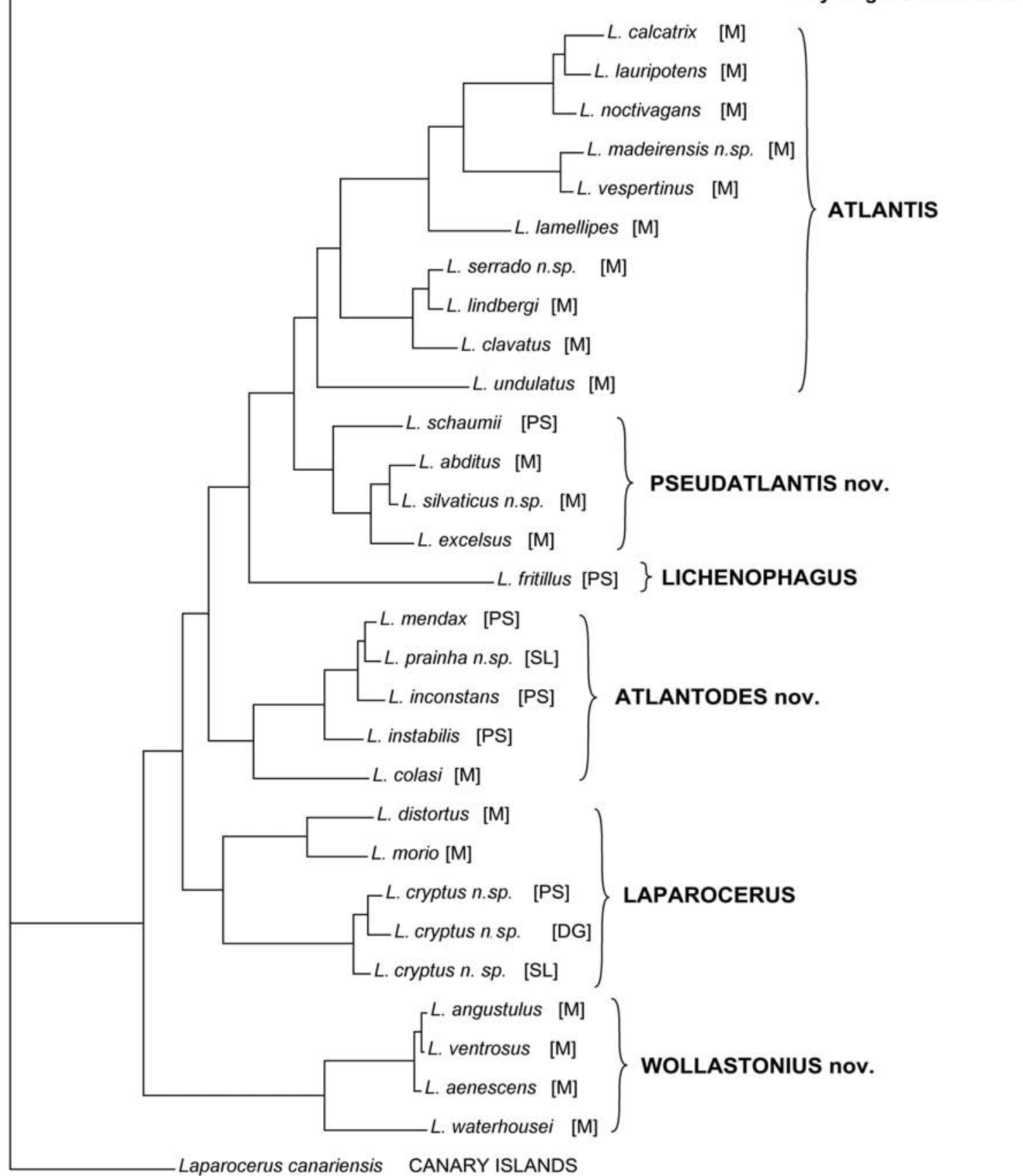

Fig. 1. - Phylogenetic tree of Laparocerus from Madeira and Porto Santo taken from Machado et al. (2008), simplified and complemented with new taxon names (see material and methods for details on this analysis). Subgenera in bold and capitals. Acronyms: $[\mathrm{M}]=$ Madeira, $[\mathrm{PS}]=$ Porto Santo, [SL] Ponta de São Lourenço, and [DG] = Deserta Grande.

Fig. 1. - Árbol filogenético de los Laparocerus de Madeira y Porto Santo tomado de Machado et al. (2008), simplificado y complementado con los nombres de los nuevos taxones (ver detalle del análisis en material y métodos). Subgéneros en letras mayúsculas y negritas. Acrónimos: $[\mathrm{M}]=$ Madeira, $[\mathrm{PS}]=$ Porto Santo, [SL] Ponta de São Lourenço, and $[\mathrm{DG}]=$ Deserta Grande. 


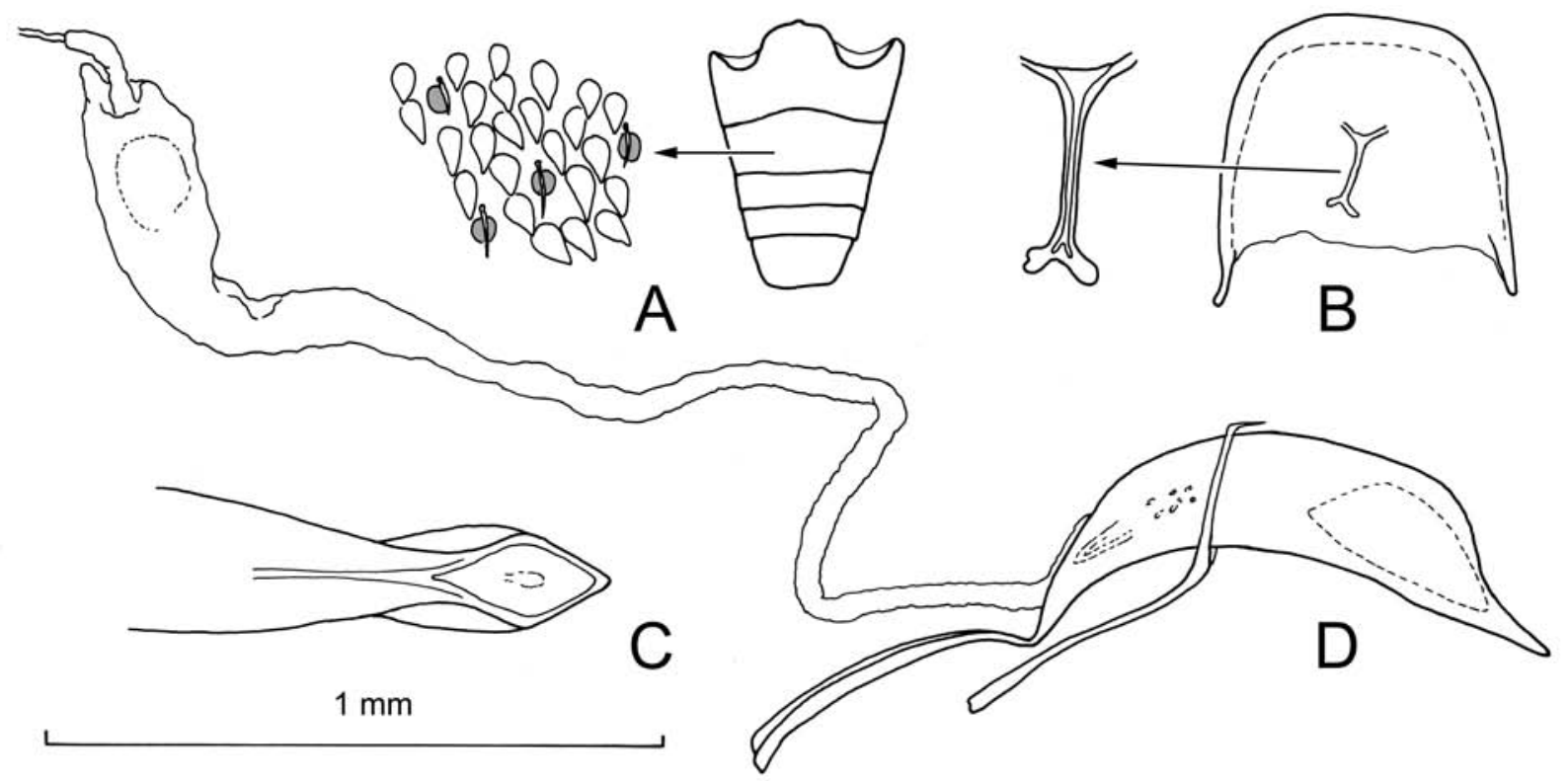

Fig. 2.-Laparocerus (Lichenophagus) fritillus. A = detail of ventral scaly vestiture, B = tergite and sternite VIII (spiculum relictum), C and D = aedeagus, C. apex, dorsal view; D. lateral view of median lobe with internal sac, temones and tegmen.

Fig. 2.-Laparocerus (Lichenophagus) fritillus. A = detalle de la vestimenta ventral de escamas, $\mathrm{B}=$ tergito y esternito VIII (spiculum relictum), C y D = edeago, C. ápice, vista dorsal; D. vista lateral del lóbulo medio con saco interno, temones y tegmen.

Its peculiar boat-shaped and flattened outline is probably related to a habitat shift (feeding on the ground on dead leaves, e.g. of Euphorbia mellifera), but all its other characters and apomorphies (e.g. the premental setae) are shared with L. morio. Machado et al. (2008) confirmed the close relationship of $L$. distortus and L. morio (see fig. 1) and thus synonymised Cyphoscelis with Laparocerus, and they further restricted subgenus Laparocerus to a small monophyletic group represented by $L$. morio, L. distortus and L. chaoensis, with L. cryptus $\mathrm{n}$. sp. to be added

According to this new composition, the subgenus Laparocerus is characterised as follows: moderate to large in size $(6-13 \mathrm{~mm})$, males larger than females (opposite to the trend in all other subgenera of Laparocerus), scape fine and abruptly capitate (fig. 3A), rostrum short and weakly tapering apically (not constricted), prementum with four setae, elytra with vestiture of small appressed scales and additional very short recumbent setae, intermesocoxal process broad and convex; mesotrochanter in male prolonged into a small posterior spine, pro- and mesotibia curved and crenulate on inner face, metatibia in male flattened and expanded (excavated for $>1 / 2$ of its length), aedea- gus with temones (apodemes) sharply demarcated from body, internal sac with two parallel rows of separated stout teeth in basal region.

Subgenus Lichenophagus Wollaston, 1854

TYPE SPECIES: Lichenophagus fritillus Wollaston, 1854, here designated.

Based on molecular evidence, Machado et al. (2008) relegated the status of Lichenophagus to that of a subgenus of Laparocerus and restricted its composition to comprise only two Madeiran species, L. fritillus from Porto Santo and L. acuminatus from Deserta Grande. Its diagnostic morphological modifications (body shape and size, form of scape, eye position, scale vestiture) are probably related to a habitat shift, both species living in foliose lichens on exposed rocks, whereas most other Laparocerus species feed on the foliage of shrubs or trees. Wollaston's original description of Lichenophagus is accurate and adequate, but it is noteworthy that males also have a spiculum relictum (sternite VIII) like all other Laparocerus, that the aedeagus is short with a peculiar pre-apical lateral constriction (unsclerotised area) and that the 
internal sac is long and tubular with an apically inserted ejaculatory duct (fig. 2).

Species from the Canary Islands attributed to Lichenophagus constitute different lineages from the Madeiran Lichenophagus and form two subclades within the Canarian Laparocerus clade (unpublished molecular data). The two subgenera established by Roudier (1957) for these Canary Islands species, Fernandezius (type species: Lichenophagus tesserula Wollaston, 1864) and Mateuius (type species: Lichenophagus acutus Wollaston, 1864) should be considered subgenera of Laparocerus Schönherr, 1834.

Subgenus Atlantis Wollaston, 1854

TYPE SPECIES: Atlantis lamellipes Wollaston, 1854, by original designation.

Laparocerus lamellipes, L. calcatrix, L. lauripotens, L. noctivagans and $L$. vespertinus share a number of characters, namely an elongate shape, clavate scape, additional long elytral hairs and apically expanded male metatibia. They were termed by Wollaston (1854) as "true Atlantides" and form a monophyletic group strongly supported by the molecular analysis conducted by Machado et al. (2008) (fig. 1). Laparocerus clavatus, $L$. lindbergi and $L$. undulatus have been considered as belonging to the subgenus Laparocerus because of their more capitate scape (figs. 3B, D) and the absence of long additional elytral hairs. However, the molecular data clearly relate them to Atlantis and not to Laparocerus (fig. 1). In fact, L. undulatus has a typical Atlantis-shaped male metatibia (fig. $3 \mathrm{G}$ ) and in L. clavatus and $L$. lindbergi (fig. $3 \mathrm{H}$ ) the apical lobe is absent, but the articular area is incipiently or clearly expanded on the internal face of the tibia. This feature of the metatibia seems to be systematically more meaningful, while the shape of the scape and development of additional hairs are apparently subject to homoplasy.

The revised composition of Atlantis here proposed is restricted to a monophyletic group of large species as discussed above, plus $L$. hobbit $\mathrm{n}$. sp., $L$. madeirensis $\mathrm{n}$. $\mathrm{sp}$. and L. serrado n. sp., which are related to L. lamellipes, $L$. vespertinus and $L$. lindbergi, respectively. Additional characters of Atlantis species are the apically strongly recurved male protibia, the first metatarsal segment being flattened and asymmetrical at its base (except in L. clavatus and $L$. serrado $\mathrm{n}$. sp.) and the very long internal sac of the aedeagus, with a bifid basal frenum, several areas of denticles and the ejaculatory duct inserted in a ventral pouch (figs. 5A, 6A-B).
Subgenus Atlantodes n. subgen.

TYPE SPECIES: Atlantis mendax Wollaston, 1854.

Wollaston (1854) termed as "aberrant Atlantides" a group of Atlantis species with a clavate scape (figs. $3 \mathrm{E}-\mathrm{F}$ ) and simple tibiae (figs. 3K-L) in both sexes, in contrast with the recurved protibia and apically expanded metatibia in the males of the "true Atlantides". In this case, the morphology is not congruent with the molecular data obtained by Machado et al. (2008), which segregate the "aberrant Atlantides" into two distant clusters: (A) L. mendax, L. inconstans, L. instabilis and L. colasi, and (B) $L$. abditus, L. excelsus and L. schaumii. Group B is genetically more closely related to the "true Atlantides" and Lichenophagus than to group A (see fig. 1). However, in all these species the aedeagus (fig. 6C) has a short internal sac with no frenum, and the ejaculatory duct is inserted at the apex (in the middle in a ventral pouch in Atlantis). Based on these relevant internal characters I am reluctant to associate group B with Atlantis and prefer to establish separate subgenera for both groups A and B in order to avoid the obvious paraphyly of the "aberrant Atlantides".

Species of group A, for which the name of Atlantodes is here proposed, are characterised by their elongate shape, absence of rounded scales, clavate scape (faintly curved in basal third or half), densely pilose legs (at least in males), simple tibiae in both sexes and the characteristics of the aedeagus described above. Laparocerus lanatus and $L$. navicularis (not included in the molecular analysis) as well as $L$. prainha $\mathrm{n}$. sp. also belong to this subgenus. The size variation within some species (e.g. L. mendax) is remarkable, with some individuals being only half the size of others.

\section{Subgenus Pseudatlantis n. subgen.}

TYPE SPECIES: Atlantis excelsus Wollaston, 1854

This subgenus comprises the monophyletic group of L. excelsus, L. abditus, L. silvaticus n. sp., L. stuebeni $\mathrm{n}$. sp. and L. schaumii. These species are characterised by their moderate size and rounded appearance (except L. stuebeni), clavate and slightly but uniformly arcuate scape, high and bulky elytra (except. L. abditus and L. stuebeni) with effaced shoulders, legs with normal pilosity (tibial brushes absent), simple metatibia in both sexes (apical lobes absent), short aedeagus (0.43$0.55 x$ length of elytra, temones included, vs. 0.64$0.80 \mathrm{x}$ in Atlantodes) and short internal sac without 

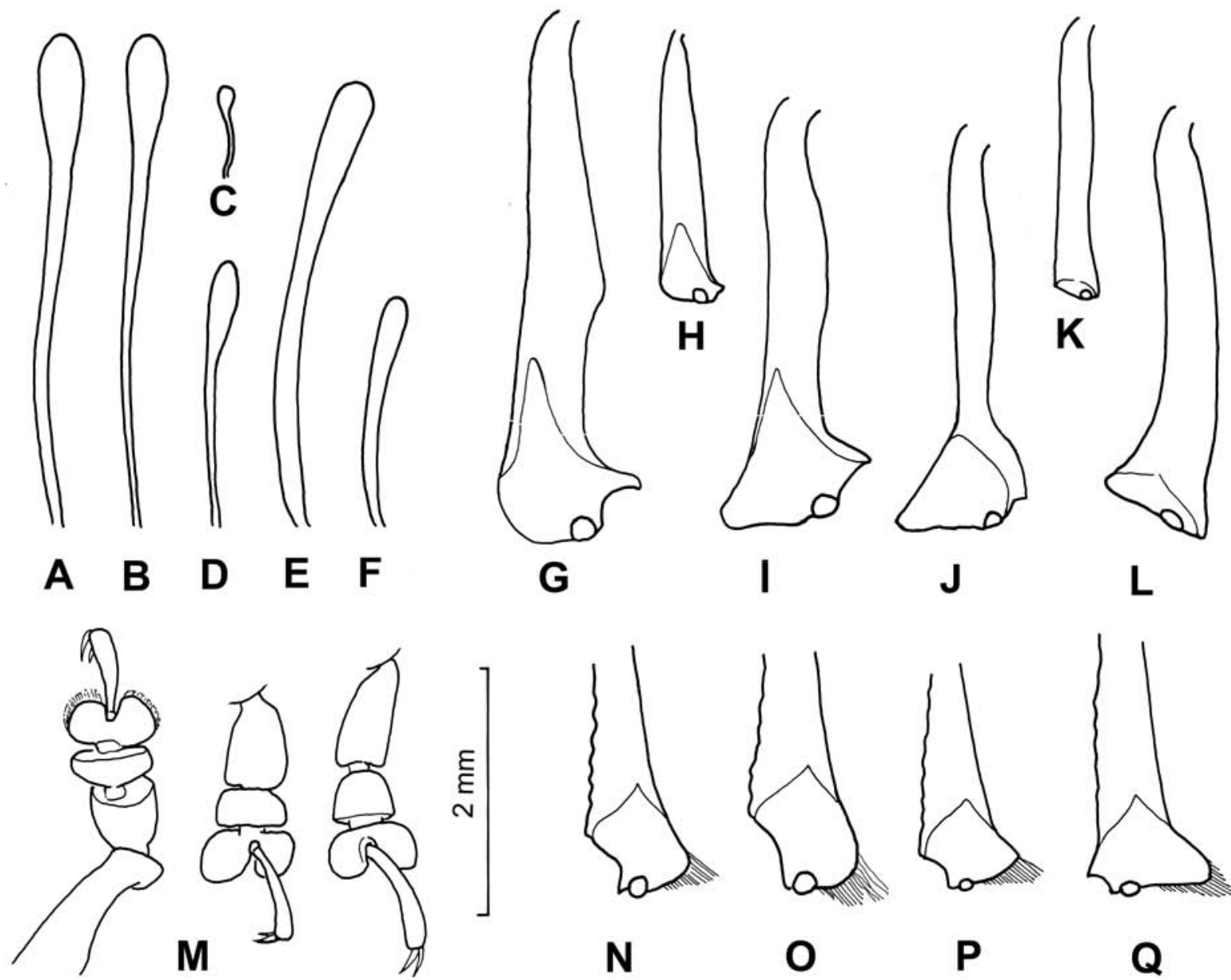

Fig. 3.- Scape of antennae A-F: A = L. (Laparocerus) morio, $\mathrm{B}=$ L. (Atlantis) undulatus, $\mathrm{C}=$ L. (Wollastonius) ventrosus, $\mathrm{D}=$ L. (Atlantis) lindbergi, $\mathrm{E}=$ L. (Atlantodes) mendax, and $\mathrm{F}=$ L. (Pseudatlantis) abditus. Metatibiae: $\mathrm{G}-\mathrm{L}:=$ L. (Atlantis) undulatus, $\mathrm{H}=$ L. (Atlantis) lindbergi, $\mathrm{I}=L$. (Atlantis) noctivagans, $\mathrm{J}=L$. (Atlantis) madeirensis $\mathbf{n} . \mathbf{s p} ., \mathrm{K}=L$. (Pseudatlantis) abditus, and $\mathrm{L}=L$. (Atlantodes) mendax. Protarsus, mesotarsus and metatarsus. $\mathrm{M}=$ L. (Atlantis) hobbit $\mathbf{n}$. sp. Male metatibiae N-Q. $\mathrm{N}=$ L. (Laparocerus) morio, $\mathrm{O}=$ L. (Laparocerus) cryptus $\mathbf{n}$. sp., $\mathrm{P}=$ L. (Laparocerus) chaoensis chaoensis, and $\mathrm{Q}=$ L. (Laparocerus) chaoensis cevadae.

Fig. 3. - Escapo de la antena A-F: $\mathrm{A}=$ L. (Laparocerus) morio, $\mathrm{B}=$ L. (Atlantis) undulatus, $\mathrm{C}=$ L. (Wollastonius) ventrosus, $\mathrm{D}=$ L. (Atlantis) lindbergi, $\mathrm{E}=$ L. (Atlantodes) mendax, y $\mathrm{F}=$ L. (Pseudatlantis) abditus. Metatibias: $\mathrm{G}-\mathrm{L}:=$ L. (Atlantis) undulatus, $\mathrm{H}=L$. (Atlantis) lindbergi, $\mathrm{I}=$ L. (Atlantis) noctivagans, $\mathrm{J}=$ L. (Atlantis) madeirensis $\mathbf{n} . \mathbf{s p} ., \mathrm{K}=L$. (Pseudatlantis) abditus, $\mathrm{y} \mathrm{L}=L$. (Atlantodes) mendax. Protarso, mesotarso y metatarso. $\mathrm{M}=$ L. (Atlantis) hobbit $\mathbf{n}$. sp. Metatibia masculina N-Q. $\mathrm{N}=$ L. (Laparocerus) morio, $\mathrm{O}=$ L. (Laparocerus) cryptus $\mathbf{n}$. sp., $\mathrm{P}=$ L. (Laparocerus) chaoensis chaoensis, y $\mathrm{Q}=$ L. (Laparocerus) chaoensis cevadae.

a frenum and with the ejaculatory duct inserted apically (see figs. 7A-B).

\section{Subgenus Wollastonius n. subgen.}

TYPE SPECIES: Omias ventrosus Wollaston, 1854.

The Laparocerus species originally described by Wollaston in the genus Omias Germar, 1817 (tribe Omiini) constitute a small monophyletic clade that represents the sister group of the rest of the Madeiran species of Laparocerus. It is here described as a subgenus and named after Thomas Vernon Wollaston (1822-1878), who so comprehensively studied the beetle fauna of Madeira. It includes the species $L$. ventrosus, L. angustulus, $L$. aenescens and L. waterhousei and can be characterised as follows: size $2.5-4.5 \mathrm{~mm}$; antenna with 


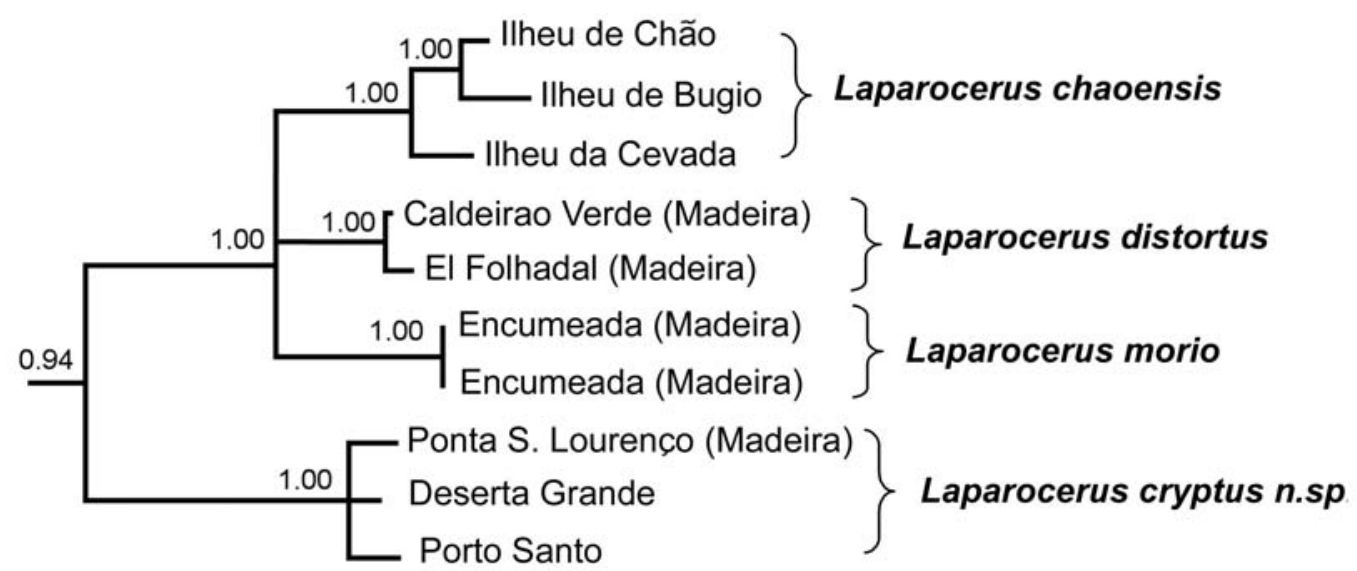

Fig. 4.- Bayesian phylogenetic consensus tree of subgenus Laparocerus for COII and 16SrRNA showing posterior probability values above $90 \%$.

Fig. 4.- Filograma bayesiano del subgénero Laparocerus para la COII y 16SrRNA mostrando los valores de probabilidad posterior superiores al $90 \%$.

scape capitate and sinuous, club broadly ovate (broader than scape), funicular segment 5 globular; eyes small, placed laterally on head and distant from border of frons (in lateral view); protibia not curved, without inner preapical setal mat; metatibia without apical expansions and additional pilosities; mesocoxal process level with procoxal process; aedeagus broad but very thin in profile, weakly sclerotised ventrally; temones very long, outlines smooth continuous with aedeagal body (no abrupt constriction); internal sac simple, much shorter than temones, without frenum or denticles and ejaculatory duct inserted apically (fig. 7E).

\section{Laparocerus (Laparocerus) chaoensis Uyttenboogaart, 1940, bon sp.}

Uytenboogaart (1940) described Laparocerus chaoensis based on 3 specimens collected in the Ilheu de Chão, one of the Desertas islets. Later (Uyttenboogart, 1947) he synonymized the species with Laparocerus morio Boheman, 1934, but Roudier (1958) indirectly resurrected the name when he described from that same locality L. morio vandeli, a junior synonym of it as recognised by Machado (2006).

The status of species is supported by the molecular data here presented (Table 1 and fig. 4). The islet samples studied from Ilheu de Chão, Bugio and the Ilheu do Desembarcadouro (also known as
Ilheu da Cevada) in the extreme east of Madeira, cluster together and show a rather high genetic pdistance (ca. 8.6-10.8\%) of the mtDnA COII with L. morio Nonetheless, the distribution of the species is remarkable (see map on fig. 14) so far as Deserta Grande, which is placed between Bugio and Chão, is apparently not inhabited by it, but by L. cryptus $\mathrm{n}$. $\mathrm{sp}$.

Roudier (1958) gives a good account of the morphological differences between Laparocerus morio from Madeira proper, and the islet subspecies he described: L. morio vandeli $(=L$. chaoensis chaoensis) and $L$. morio cevadae $(=L$. chaoensis cevadae Roudier, 1958 nov. comb.). Both taxa are well characterised by their aedeagus, being the median lobe bi-sinuate (not straight) in its concave part, and showing a much triangular and shorter apical plate (in dorsal view). The internal sac is armed at base with two parallel rows of 3032 large denticles (ssp. chaoensis) and 50-70 (ssp. cevadae) instead of the 9-13 of Laparocerus morio or L. cryptus. Moreover, the apical outer angle of the male metatibiae are clearly more protruding than in L. morio, (strongest in L. chaoensis cevadae, fig. 3Q) and the normal size of both males and females is generally smaller.

Male specimens from the almost inaccessible rock of Bugio, kindly collected by the park ranger Isamberto Silva (7 $0^{\top} \sigma^{\top}$ and 6 우 우, 20-7-2008), bear 27-30 denticles in the aedeagus and show almost the same metatarsal conformation as the males 


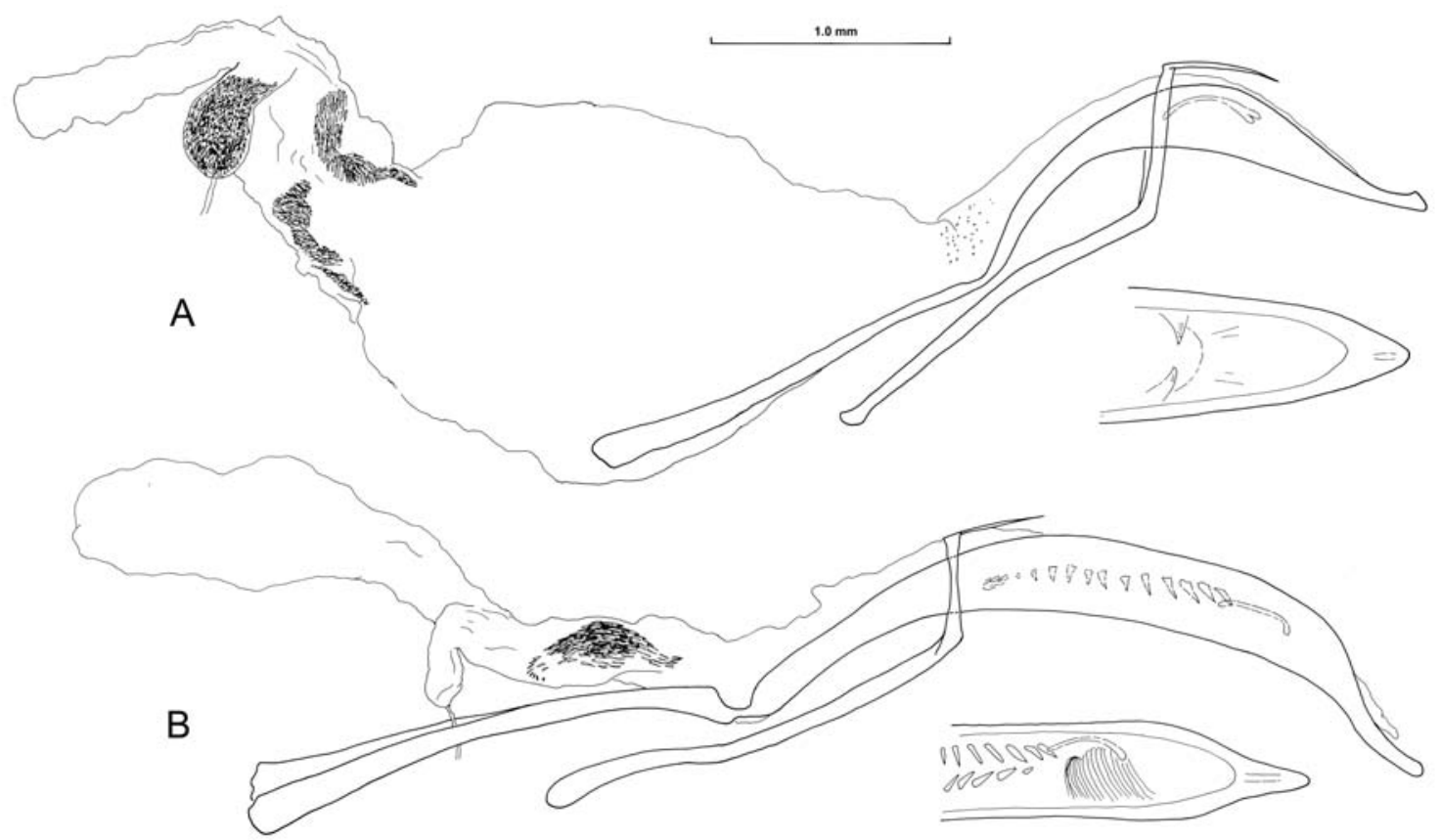

Fig. 5.- Aedeagus, lateral, apex: $\mathrm{A}=$ Laparocerus (Atlantis) hobbit $\mathbf{n} . \mathbf{s p}$. and $\mathrm{B}=$ L. (Laparocerus) cryptus $\mathbf{n} . \mathbf{s p}$.

Fig. 5.- Edeago, en vista lateral, y ápice: A = Laparocerus (Atlantis) hobbit $\mathbf{n} . \mathbf{s p}$. y $\mathrm{B}=$ L. (Laparocerus) cryptus $\mathbf{n} . \mathbf{s p}$.

from Ilheu de Chão. However, their genetic distance $(3.8 \%)$ is high enough to consider them as a separate subspecies, but we prefer to wait until more material can be examined. In L. chaoensis cevadae, the notch of the internal apical angle of the metatibia is extremely short and preceeded by a sharp point (fig. 3Q).

\section{Laparocerus (Laparocerus) cryptus $\mathrm{n} . \mathbf{s p}$.} (figs. 3O, 5B, 8A, 9A, 10A)

Material examined: Holotype male: Porto Santo: Capella da Graça, 220 m. (28S 0376463 3660206), 28-2-2004, leg. A. Machado (TFMC CO-15598). Paratypes: Same locality, 28-22004 (1 ex.), 24-11-2001 (4); Campo do Baixo, 5 m, 24-112001, 10 m (5), 4-8-2000 (2); Pico do Castelo, $400 \mathrm{~m}$, 4-8-2000 (12), 24-11-2001 (4); Pico de Ana Ferreira, W., 1-112005 (2); Pico do Facho, ladera N., 1-11-2005 (1); Fonte da Areia, 23 m, 28-2-2004, leg. A. Machado (13, AMC); Mesta norte, 6-4-1977, Aeroporto (8), 6-4-1977 (12), leg. J.G. Talavera. (TFMC); Capela de Graça, 220 m, 28-2-2004 (8); Fonte da Areia, 23 m (3); Ermita Campo de Baixo, 10 m, 292-2004 leg. A. Aguiar (2, AAC).

Other material examined: More than 150 specimens from Ponta de São Lourenço, Caniçal, Prainha, Porto Santo and Deserta Grande. One pair of this species, confirmed by male genitalia, was collected under a stone at the entrance of the lighthouse in the Ilheu de Chão. An introduction with supplies coming from Deserta Grande is plausible.The islet is abundandtly populated by L. chaoensis, of which more than 100 specimens were collected that same day.

DNA sequences. GenBank accession numbers: EF583359 (COII) and EF583425 (16S rRNA) from Ponta de São Lourenço, Madeira; EF583360 (COII) and EF583426 (16S rRNA) from Pico do Castelo, Porto Santo, and EF583361 (COII) and EF583427 (16S rRNA) from Chão da Doca, Deserta Grande.

Dimensions (mm): Holotype $\left(0^{7}\right)$. Length: total (excl. rostrum) 9.92, head 1.50, rostrum 0.86, eyes 0.32 , scape 2.35 , funicle 2.52 (segments $1-4$ respectively $0.52,0.50,0.38,0.30$ ), club 0.64 , pronotum 2.55 , elytra 6.96 , protibia 2.45 , mesotibia 2.15, metatibia 2.65. Width: head (across eyes) 1.48, head (between eyes) 0.90, rostrum (with pterygia) 1.04, rostrum (minimum dorsal /ventral) $0.80 / 1.04$, eyes 0.42 , scape (apically) 0.19 , club 0.21 , pronotum (anterior /maximum /posterior) $1.65 / 3.02 / 2.57$, elytra (maximum) 4.60. Height: abdomen 3.25.

DiAgNosis: Length: $0^{7} 0^{7}:$ 9.8-12.7, ㅇ ㅇ: 6.2-9.6 $\mathrm{mm}$. Same habitus as Laparocerus morio, but males usually with broader elytra, (like females), vestiture of appressed scales shorter (not or hardly overlapping), male metatibia (fig. 30) with less 
developed crenulation at inner margin, outer apical margin almost straight (angle not protruding) and the smooth articular area more elongate and rectangular (trapezoidal in L. morio; triangular in $L$. chaoensis ). Aedeagus (fig. 3) similar to that of $L$. morio, with elongated apex and two parallel rows of 12-13 large denticles at base of internal sac (3031 in L. chaoensis chaoensis; 50-70 in L. chaoensis cevadae).

ETYmology: Adjective derived from the Greek cryptós, hidden, in reference to the veiled identity of this insect (difficult to distinguish morphologically from $L$. morio.

DisTRIBUTION AND ECOLOGY: Laparocerus chaoensis $\mathrm{n}$. sp. occurs in the semi-arid habitats of Ponta de São Lourenço (Madeira) and the islets of Porto Santo and Deserta Grande. It is common in winter and active by night, having been beaten from several plant species (e.g. Atriplex, Cynara, Cistus, Erica, Euphorbia, Galactites, Lotus), and during the daytime it can be easily found under stones. Its vicariant in Madeira proper, L. morio, is more common in summer.

REMARKs: Machado et al. (2008) found that specimens with the habitus of L. morio from Ponta de São Lourenço (East peninsula of Madeira), Porto Santo and Deserta Grande clustered together, showing closer genetic relationship between them (COII p-distance 2.6-3.3\% ) than with specimens of L. morio from the rest of Madeira (Table 1). The pdistances obtained with the latter specimens were extraordinarily high (11.0-12.2\%); much higher, for instance, than between $L$. morio and L. distortus (5.9-6.3\% which are morphologically very distinct). The hypothesis of L. cryptus being a cryptic species separate from the rest of species in the subgenus is supported by the phylogenetic tree obtained (fig. 4), notwithstanding that it is hardly distinguishable from L. morio (see diagnosis). There are no obvious significant allometric differences, except that males of L. chaoensis cryptus usually (but not always) have broader elytra (similar to females).

Laparocerus morio is distributed in Madeira proper with the exception of the extreme eastern peninsula of Ponta de Sâo Lourenço, where it is replaced by populations of $L$. cryptus, and the adjacent islet of Ilheu do Desembarcadouro, by $L$. chaoensis cevadae (see fig. 14). It is known from other such groups (e.g. land snails, Cook et al. 1990) that the Ponta Sâo Lourenço has a greater faunal affinity with its extending arc of islets of the Desertas and with Porto Santo, than with the rest of Madeira. In fact, the possibility of the Ponta de Sao Lourenço having been a separate islet that recently fused with Madeira along the valley of Machico is currently being investigated (Susana Prada, pers. com.).

Laparocerus (Atlantis) madeirensis n. sp. (figs. 3J, 6B, 8B, 9B, and 11A)

Material examined. Holotype: Madeira: Encumeada - El Folhadal (UTM 28S 030950362581$) 1000$ m. 1 ㅇ 1-8-2000, leg. A. Machado (TFMC, reg. CO-15599). Paratypes: Same data, 3 exx (AMC); Encumeada, 1030 m, 10 exx 23-2-2004, 2 exx 18-9-2004 leg. A. Machado (9 AMC, 1 NHM, 2 MNHN), Montado dos Pesseguerios 1300 m. 5 exx. 30-7-1989, leg. A. Machado (AMC). Encumeada. 5 exx. 7-2-1983, leg. G. Israelson. (NRS, Coll. Israelson).

Not paratypes: Madeira, Ribeiro Frío, Levada 780 m. 2 exx. 15-9-2004, leg. A. Machado. (AMC). Without locality and date, 1 ex. No date, leg. Pécoud (MNHN, Coll. General Ruter) [labelled "Canaries, Pécoud" / "probabl. Madére"].

DNA sequences. GenBank accession numbers: EF583335 (COII) and EF583408 (16S rRNA) from Ribeiro Frio, Madeira.

Dimensions, holotype $\left(O^{x}\right)$. Length: total (without rostrum) $7.45 \mathrm{~mm}$, head $1.20 \mathrm{~mm}$, rostrum $0.48 \mathrm{~mm}$, eyes $0.48 \mathrm{~mm}$, scape $1.66 \mathrm{~mm}$, funicle $2.88 \mathrm{~mm}$, articles $\left(1^{\mathrm{st}} / 2^{\text {nd }} / 3^{\text {rd }} / 4^{\text {th }}\right) 0.48 / 0.46 / 0.28$ $/ 0.28 \mathrm{~mm}$, club $0.62 \mathrm{~mm}$, pronotum $1.50 \mathrm{~mm}$, elytra $5.15 \mathrm{~mm}$, and tibiae (pro- /meso- /meta-) 2.05 $/ 1.95 / 2.10 \mathrm{~mm}$. Width: head (with eyes) $1.12 \mathrm{~mm}$, head (between eyes) $1.12 \mathrm{~mm}$, rostrum (with pterygia) $0.84 \mathrm{~mm}$, rostrum (minimum dorsal /ventral) $0.54 / 0.75 \mathrm{~mm}$, eyes $0.36 \mathrm{~mm}$, scape (apicad) 0.16 $\mathrm{mm}$, club $0.16 \mathrm{~mm}$, pronotum (anterior /maximum /posterior) $1.15 / 1.75 / 1.60 \mathrm{~mm}$, and elytra (maximum) $3.20 \mathrm{~mm}$. Height: abdomen $2.15 \mathrm{~mm}$.

Description. Males: A medium sized Laparocerus (length without rostrum: 7.2-7.9 $\mathrm{mm}$ ), of oblong-elliptical shape. Integument subnitid (head and pronotum alutaceous), piceous-brown, antennae and tarsi lighter; elytra with long hairs and scarce vestiture of decumbent scales, forming few maculae. Antennae: Scape clavate, slightly arcuate, 1.1 length of pronotum, funicle 1.7 length of scape, $1^{\text {st }}$ and $2^{\text {nd }}$ articles equal, club long and thin (not broader than scape). Head with short rostrum; pterygia short, weakly protruding; prorostrum ill defined; metarostrum strongly narrowed dorsally towards base, with longitudinal rugosity; frons weakly depressed, frontal furrow long and linear, extending along metarostrum. Eyes large (as long as rostrum in dorsal view), oblique, partially invading frons, less convex (convexity 30\%) and cusp 


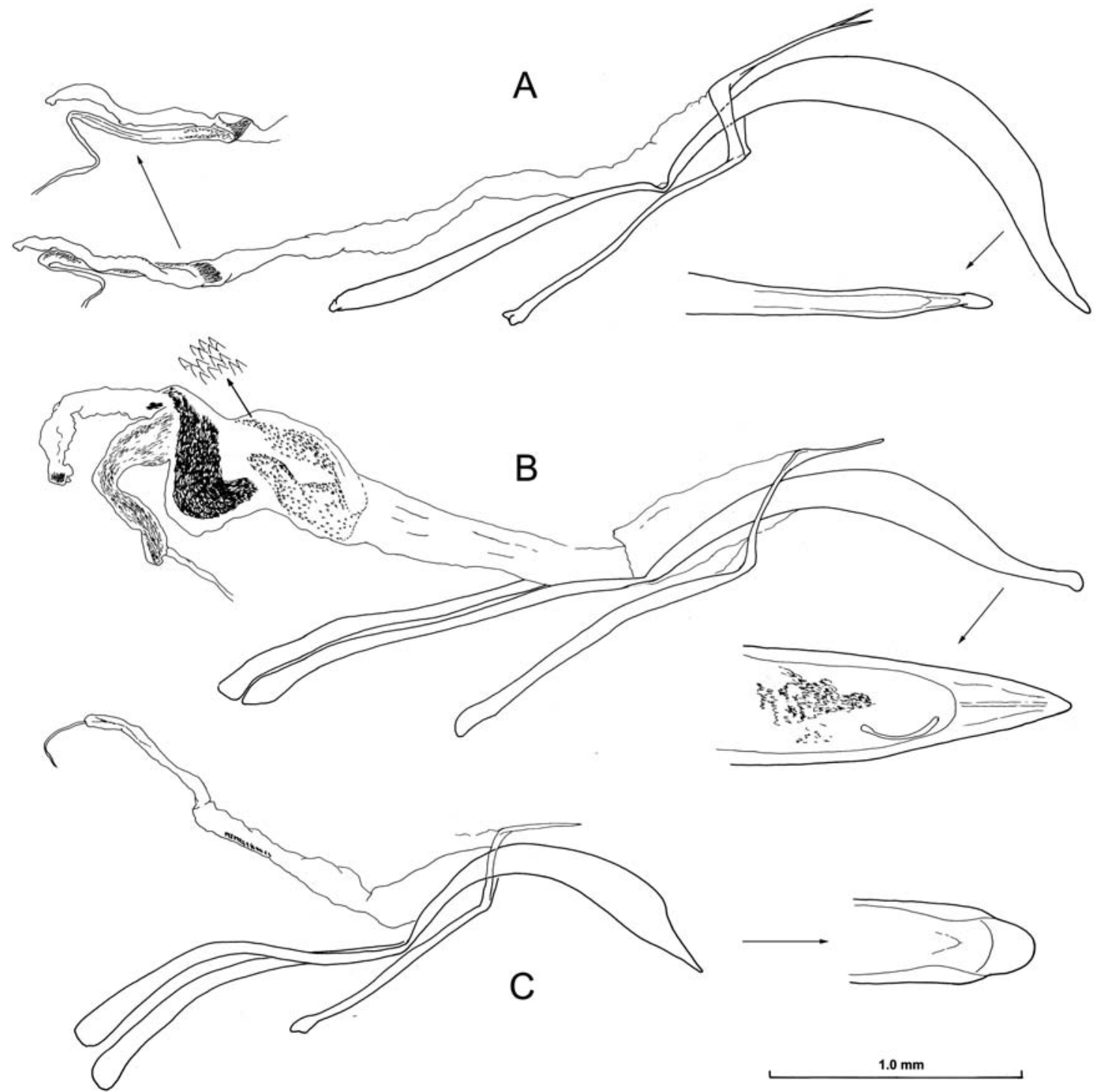

Fig. 6.- Aedeagus, lateral, apex: $\mathrm{A}=$ L. (Atlantis) serrado n. sp., $\mathrm{B}=$ L. (Atlantis) madeirensis n. $\mathbf{s p}$. , and $\mathrm{C}=$ L. (Atlantodes) prainha $\mathbf{n}$. sp.

Fig. 6.- Edeago, en vista lateral, y ápice: $\mathrm{A}=$ L. (Atlantis) serrado $\mathbf{n} . \mathbf{s p} ., \mathrm{B}=$ L. (Atlantis) madeirensis $\mathbf{n} . \mathbf{s p} . \mathrm{y} \mathrm{C}=$ L. (Atlantodes) prainha $\mathbf{n} . \mathbf{s p .}$

shifted backwards. Pronotum small, moderately transverse $(\mathrm{L} / \mathrm{W}=0.86)$, widest at middle, sides almost uniformly curved; anterior and posterior margins slightly concave, not rimmed; disc weakly convex, uneven (with premarginal depression). Integument with strong isodiametric microreticulation, somewhat dull (as in head), densely covered by macro-punctures (not coalescent), beset with sparse vestiture of small golden, recumbent seti- form scales. Scutellum broad-triangular, with few scales. Elytra $3.4 \mathrm{x}$ as long and $1.8 \mathrm{x}$ as wide as pronotum, oval-elliptical in shape, with rounded shoulders; sides evenly convex, maximum breadth slightly behind middle, apex slightly acuminate; disc somewhat flattened, striae marked by small, deep punctures, intervals in general noticeably subconvex. Integument alutaceous (with transverse impressions), shiny, with sparse vestiture of 
decumbent setiform golden/ coppery scales (not coalescent), and protruding slanting whitish hairs, double in size and erect in apical fourth (almost as long as first metatarsal segment). Legs hairy, short and robust; protibiae straight, externally ridged, shortly incurved at apex, with outer angle rounded, inner angle acute with mucro; mesotibiae slightly edged, incurved, with mucro, and apical third with internal comb of very long hairs; metatibiae at apex abruptly and broadly expanded (articular area triangular, extending onto inner face) with posterior lobe triangular and pointed but not exceeding the length of the first tarsal article; anterior lobe much less protruding, hump-like and shortly notched apically (fig. 3J); first metatarsal article rectangular, with asymmetric base. Venter: Integument shiny with dense scale coverage and pubescence (short); inter-mesocoxal process cariniform, weekly convex; coxae hairy; last ventrite dull, punctured, truncated. Abdominal transverse convexity 65\%. Genitalia. Aedeagus 0.7x length of elytra; median lobe slender, weakly arcuate, uniformly tapering apicad, with tip shortly bent downwards; internal sac with mid-ventral diverticulum, two complex dense fields of denticles near base of muscular sheath, and small group of teeth apicad (fig. 6B).

Females. Length without rostrum, 6.9-7.7 mm. Similar to male, but elytra more elliptic and convex (intervals scarcely convex). Legs noticeably more slender; femora less incrassate and tibiae simple (devoid of long hairs or mesotibial apical lobe); first metatarsal article less asymmetric. Sternite VIII apically rounded (fig. 8B). Spermatheca with very small duct lobe and almost obsolete gland lobe (fig. 9B). Hemisternites with elongated apical styli (fig. 4).

ETymology. The specific epithet refers to the island of Madeira, where the species is endemic, and is an adjective.

DisTRIBUTION AND ECOLOGY. Laparocerus madeirensis $\mathrm{n}$. $\mathrm{sp}$. is endemic to the island of Madeira, having being found in the central and eastern forest districts, at high elevation (780-1000 m). It seems to be linked to the hyper-humid laurel forest environment, but, in contrast to most species of the L.lamellipes-group, it is much less common. L. madeirensis n. sp. is active at night and has been beaten from Vaccinium padifolium (Ericaceae), Laurus azorica (Lauraceae) and once from Teline maderensis (Leguminosae).

REMARKS. L. madeirensis $\mathrm{n}$. sp. belongs to the group of L. lamellipes within subgenus Atlantis, and is most closely related to $L$. vespertinus
Wollaston, 1854. It is easy to recognise by its elliptical outline (shoulders effaced) and, especially, by the heavily punctured pronotum, which is dull and somewhat uneven in a form unparalleled within the group. The form of the apical anterior lobe of the male protibia varies much in L. noctivagans, but in L. madeirensis it is more constant in shape, subparallel to the axis of the tibia, shortly notched, and never sharp-pointed. This anterior lobe is absent in L. lamellipes, L. hobbit n. sp. and L. vespertinus.

\section{Laparocerus (Atlantis) hobbit n. sp.}

(figs. 3M, 5A, 8G, 9C, and 10B)

Material examined. Holotype. Madeira: Faja da Nogueira, $400 \mathrm{~m} 10^{7}$ 24-7-2000, leg. A. Machado (MCTF CO-15600). Paratypes. Same locality, 24-6-2008 3 exx leg. A. Machado (AMC), 2 exx leg. A. Aguiar (AAC); Madeira: São Jorge, Levada Nova, 600 m, 1 ㅇ 29-7-2000, leg. A. Machado (AMC).

Dimensions, holotype $\left(O^{7}\right)$. Length: total (without rostrum) $9.10 \mathrm{~mm}$, head $2.00 \mathrm{~mm}$, rostrum $0.85 \mathrm{~mm}$, eyes $0.58 \mathrm{~mm}$, scape $2.10 \mathrm{~mm}$, funicle $3.20 \mathrm{~mm}$, articles $\left(1^{\mathrm{st}} / 2^{\text {nd }} / 3^{\text {rd }} / 4^{\text {th }}\right) 0.50 / 0.64 / 0.38$ $10.28 \mathrm{~mm}$, club $0.68 \mathrm{~mm}$, pronotum $2.00 \mathrm{~mm}$, elytra $6.20 \mathrm{~mm}$, and tibiae (pro- /meso- /meta-) 2.65 $/ 2.45 / 2.85 \mathrm{~mm}$. Width: head (with eyes) $1.32 \mathrm{~mm}$, head (between eyes) $0.60 \mathrm{~mm}$, rostrum (with pterygia) $1.10 \mathrm{~mm}$, rostrum (minimum dorsal /ventral) $0.60 / 0.90 \mathrm{~mm}$, eyes $0.50 \mathrm{~mm}$, scape (apicad) 0.20 $\mathrm{mm}$, club $0.20 \mathrm{~mm}$, pronotum (anterior /maximum /posterior) $1.45 / 2.25 / 2.00 \mathrm{~mm}$, and elytra (maximum) $3.55 \mathrm{~mm}$. Height: abdomen $3.00 \mathrm{~mm}$.

Diagnosis. Size 8.9-9.1 mm. Similar to $L$. lamellipes, but scape more sinuous (slightly and uniformly arcuate in L. lamellipes); first article of funicle clearly shorter than second; pronotum laterally more uniformly curved; elytra somewhat narrower and more cylindrical, more depressed at base and suture slightly elevated (keeled) in apical third; additional protruding whitish setae and tufts of thick blackish setae only in apical third of elytra. Legs more robust, with broader tibiae; male protibiae similarly excavated but less curved in middle, with strong brief preapical constriction; $1^{\text {st }}-2^{\text {nd }}$ tarsal segments incrassated in both sexes, the $2^{\text {nd }}$ markedly transverse (longitudinal in L. lamellipes); mesotibiae more arcuate.

Etymology. The specific epithet is a noun in apposition which refers to the Hobbits of J. R. R. Tolkien (The Lord of the Rings), a literary fictitious race of people who have big and hairy feet; a metaphor of the swollen and hairy tarsi characteristic of this species. 
DisTRIBUTION AND ECOLOGY. The few known specimens of $L$. hobbit $\mathrm{n}$. sp. were collected at night in the northern laurel-forest district of Madeira. The specimens from Faja da Nogueira were beaten from Persea indica (Lauraceae) mixed with Laurus novocanariensis (Lauraceae), and the female from São Jorge was beaten from mixed vegetation of Clethra arborea (Clethraceae), Euphorbia mellifera (Euphorbiacea) and Rubus ulmifolius (Rosacea), together with many specimens of $L$. lamellipes, which is a rather common species.

REMARKS. L. hobbit $\mathrm{n}$. sp., is presumably the sister species of $L$. lamellipes. The aedeagi are basically the same; both species share the presence of tufts of black setae on the elytra (synapomorphy), and the male metatibiae have developed only the posterior apical lobe. L. hobbit is hard to distinguish from $L$. lamellipes with the naked eye. It is necessary to inspect the tarsi, which are abnormally incrassate and transverse in this species $\left(\mathrm{L} / \mathrm{W} 2^{\text {nd }}\right.$ protarsal segment $=0.45$, mesotarsal $=0.58$, and metatarsal $=0.70)$, a feature unparalleled in Laparocerus (fig. 3M). In L. hobbit, the pilosity of elytra is developed only in the apical half. The same happens in specimens of L. lamellipes found south and eastwards from Encumeada (pass in the mid of Madeira). while specimens found north and westwards of Encumeada bear pilosity throughout the whole elytra (a subspecies?).

\section{Laparocerus (Atlantis) serrado $\mathbf{n}$. sp.}

(figs. 6A, 8E, 9D, and 11B)

Material examined. Holotype: Madeira: infra Eira do Serrado, 915 m. (28S 0316055 3620682), 1 o $^{7}$ 27-2-2004, leg. A. Machado (MCTF CO-15601). Paratypes: same locality and date, $50^{7} 0^{7} 1$ ㅇ (AMC); $20^{7} 0^{2} 2$ 우 이 leg. A. Aguiar (AAC).

DNA sequences. GenBank accession numbers: EF583353 (COII) and EF583421 (16S rRNA) from Eira do Serrado, Madeira.

Dimensions, holotype $\left(\sigma^{7}\right)$. Length: total (without rostrum) $6.60 \mathrm{~mm}$, head $1.38 \mathrm{~mm}$, rostrum $0.76 \mathrm{~mm}$, eyes $0.34 \mathrm{~mm}$, scape $1.82 \mathrm{~mm}$, funicle $1.97 \mathrm{~mm}$, articles $\left(1^{\text {st }} 2^{\text {nd }} / 3^{\text {rd }} / 4^{\text {th }}\right) 0.46 / 0.39 / 0.26$ $10.26 \mathrm{~mm}$, club $0.64 \mathrm{~mm}$, pronotum $1.40 \mathrm{~mm}$, elytra $4.70 \mathrm{~mm}$, and tibiae (pro- /meso- /meta-) 1.82 $/ 1.68 / 1.92 \mathrm{~mm}$. Width: head (with eyes) $0.92 \mathrm{~mm}$, head (between eyes) $0.66 \mathrm{~mm}$, rostrum (with pterygia) $0.74 \mathrm{~mm}$, rostrum (minimum dorsal /ventral) $0.48 / 0.62 \mathrm{~mm}$, eyes $0.28 \mathrm{~mm}$, scape (apicad) 0.16 $\mathrm{mm}$, club $0.19 \mathrm{~mm}$, pronotum (anterior /maximum /posterior) $1.08 / 1.71 / 1.54 \mathrm{~mm}$, and elytra (maximum) $2.67 \mathrm{~mm}$. Height: abdomen $2.25 \mathrm{~mm}$.
Diagnosis. Size $0^{\top} \sigma^{x}=5.7-6.5 \mathrm{~mm}$, 우 우 $=5.5$ $5.7 \mathrm{~mm}$. Similar to L. clavatus, but eyes less prominent (convexity $35 \%$ instead of $45 \%$ ); funicle longer; pronotum laterally more evenly rounded, less transverse and narrower at base, punctures more precise; elytra narrower especially at base, base straight to slightly concave (not markedly bisinuate), shoulders marked but not or not much advanced; nodosity of male elytra much less developed (obsolete in females), with less noticeable patches of dense scales. Protibiae almost symmetrical at apex, with tiny mucro (curved and strong mucro in L. clavatus); spines of internal border of female tibiae less developed or absent (2-3 in $L$. clavatus). Median lobe of aedeagus laterally constricted as in L. clavatus, but more curved in profile. Female sternite VIII less acute-pointed (fig. 8E).

ETymology. The specific epithet is a noun in apposition taken from the type locality Eira do Serrado, which presumably derives from "serra" = mountain-range, in Portuguese.

Distribution And ECOlOgy. The small series of Laparocerus serrado n. sp. was collected on the cliffs adjacent to the old tunnel below Eira do Serrado, in the central mountain range of the island of Madeira. It was beaten at night from Teucrium betonicum (Lamiaceae) growing intermixed with Erica (Ericaceae) and Rubus (Rosaceae).

REMARKS. Laparocerus serrado n. sp. is somewhat intermediate between $L$. clavatus and L. lindbergi. According to molecular data (fig. 1) its sister species is $L$. lindbergi, but it resembles much more closely $L$. clavatus, particularly the males, due to the undulated uneven intervals, with bumps clothed with patches of clear scales (this nodosity is much more developed in both sexes in L. clavatus), and by still marked but less prominent (not porrect) humeri in males. The pronotum in L. clavatus is noticeably much wider at the base than anteriorly; in $L$. serrado the sides are more uniformly and strongly curved, and in L. lindbergi the pronotum is narrower with less curved sides. In the latter species, the male protibiae are extraordinarily recurved and twisted, much more than in any other species of Laparocerus.

\section{Laparocerus (Pseudatlantis) silvaticus n. sp.} (figs. 7B-D, 8C, 9E, and 12A)

Material eXAmined. Holotype: Madeira: Rabaçal (UTM 28S 03000543626877$) 1050$ m. $10^{7}$ 27-7-2000, leg. A. Machado (TFMC, reg. CO-15602). Paratypes: 10 exx same 


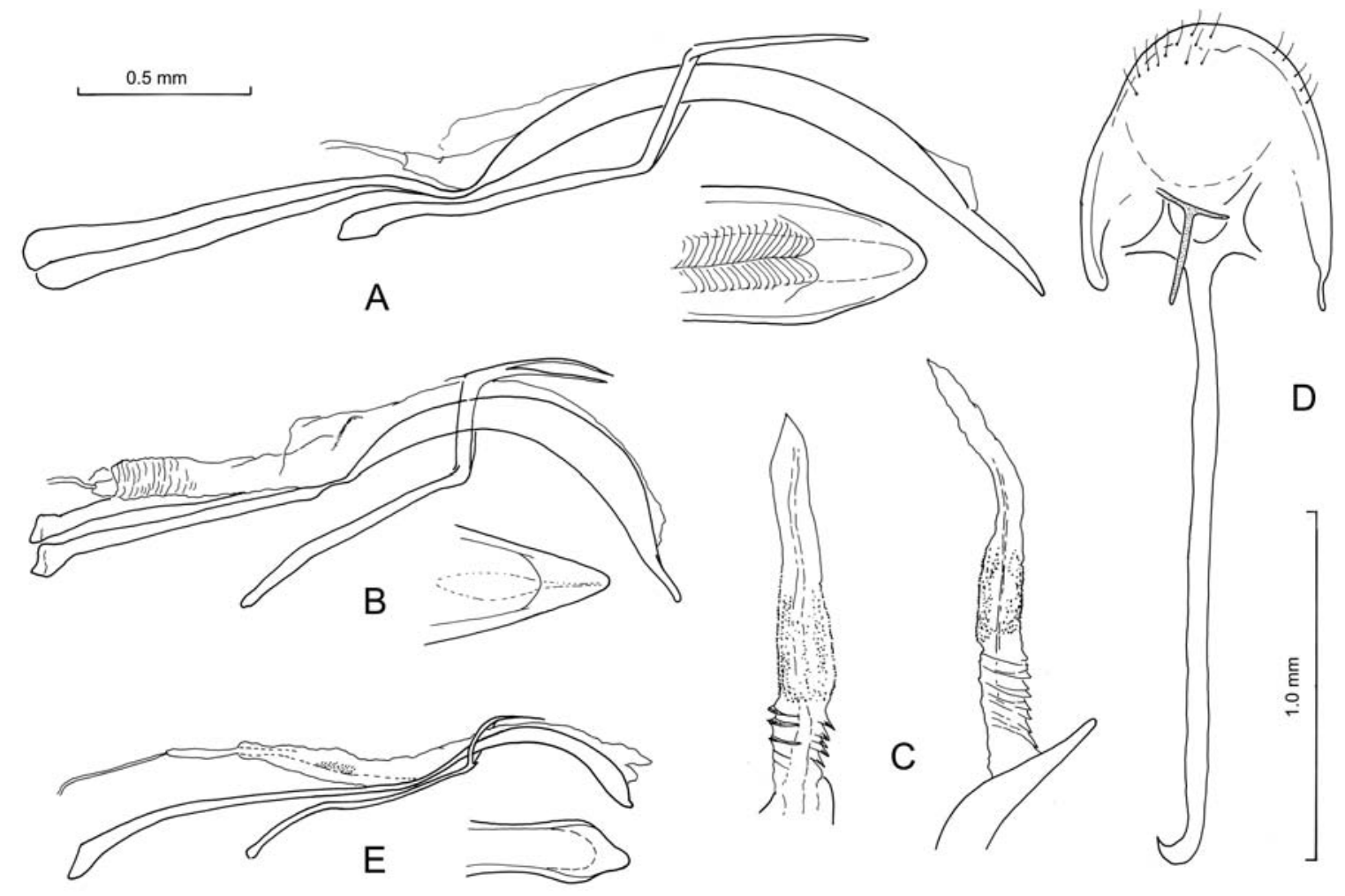

Fig. 7.- Laparocerus (Pseudatlantis) stuebeni $\mathbf{n} . \mathbf{s p .} \mathrm{A}=$ aedeagus, lateral, apex. L. (Pseudatlantis) silvaticus $\mathbf{n} . \mathbf{s p} . \mathrm{B}=$ aedeagus, lateral, apex, $\mathrm{C}=$ everted internal sac, and $\mathrm{D}=$ tergite VIII, spiculum gastrale, and spiculum relictum (in grey). $L$. (Wollastonius) waterhousei, $\mathrm{E}=$ aedeagus, lateral, apex.

Fig. 7.-Laparocerus (Pseudatlantis) stuebeni n. sp. A = edeago, en vista lateral, y ápice. L. (Pseudatlantis) silvaticus n. sp. B = edeago, en vista lateral, y ápice, $\mathrm{C}=$ saco interno evaginado y $\mathrm{D}=$ terguito VIII, spiculum gastrale y spiculum relictum (en gris). L. (Wollastonius) waterhousei, $\mathrm{E}=$ edeago, en vista lateral, y ápice.

locality and data, 39 exx; 9-8-2007 (AMC, 2 NHM, 2 ZMUH); 1 exx. 4-7-1971, leg. T. Palm. (ZMUL); 980 m. 1 exx. 2-81983, leg. D. Erber (MNCN).

Not paratypes: Madeira: Pico da Faja da Lenha, $1350 \mathrm{~m}$. 1 ex. 3-8-2000, leg. A. Machado (AMC); Levada do Caldeirao (Lombo dos Cedros) 850 m.1ex. 20-7-2000, leg. P. Stüben (AMC); Queimadas: Levada Serra do Fatal - Cha, 820 m. 1 exx. 27-8-1983, leg. D. Erber (AMC).

DNA sequences. GenBank accession numbers: EF583335 (COII) and EF583408 (16S rRNA) from Ribeiro Frio, Madeira.

Dimensions, holotype $\left(O^{7}\right)$. Length: total (without rostrum) $6.05 \mathrm{~mm}$, head $1.30 \mathrm{~mm}$, rostrum $0.62 \mathrm{~mm}$, eyes $0.32 \mathrm{~mm}$, scape $1.48 \mathrm{~mm}$, funicle $1.44 \mathrm{~mm}$, articles $\left(1^{\text {st }} / 2^{\text {nd } / ~} 3^{\text {rd }} / 4^{\text {th }}\right) 0.29 / 0.38 / 0.18$ $10.18 \mathrm{~mm}$, club $0.52 \mathrm{~mm}$, pronotum $1.25 \mathrm{~mm}$, elytra $4.40 \mathrm{~mm}$, and tibiae (pro- /meso- /meta-) 1.74 $/ 1.52 / 1.88 \mathrm{~mm}$. Width: head (with eyes) $1.02 \mathrm{~mm}$, head (between eyes) $0.60 \mathrm{~mm}$, rostrum (with pterygia) $0.76 \mathrm{~mm}$, rostrum (minimum dorsal /ventral)
$0.60 / 0.70 \mathrm{~mm}$, eyes $0.26 \mathrm{~mm}$, scape (apicad) 0.14 $\mathrm{mm}$, club $0.15 \mathrm{~mm}$, pronotum (anterior /maximum /posterior) $1.17 / 1.65 / 1.47 \mathrm{~mm}$, and elytra (maximum) $3.15 \mathrm{~mm}$. Height: abdomen $2.40 \mathrm{~mm}$.

Diagnosis. Size $0^{7} 0^{7}=5.0-5.9 \mathrm{~mm}$, 우 우 =5,3-6.4 $\mathrm{mm}$. Similar to Laparocerus abditus, but integument less shiny, scape as long as pronotum, decumbent pilosity of pronotum and elytra conspicuous but 0.5 $0.7 \mathrm{x}$ shorter and more compact and uniform (pile 1/4 length of onychium); elytra broader at base and much stouter in profile; tibiae without mucro, protibiae of male almost straight (not shortly incurved at apex). Aedeagus (fig. 7B-D), apex in profile sinuous, in dorsal view triangular (straight and blunt in L. abditus). Female tergite VIII tongue-shaped, not triangular (fig. 8C). Males and females rather similar in outline and leg configuration (female elytra slightly more quadrangular, with flatter intervals). 


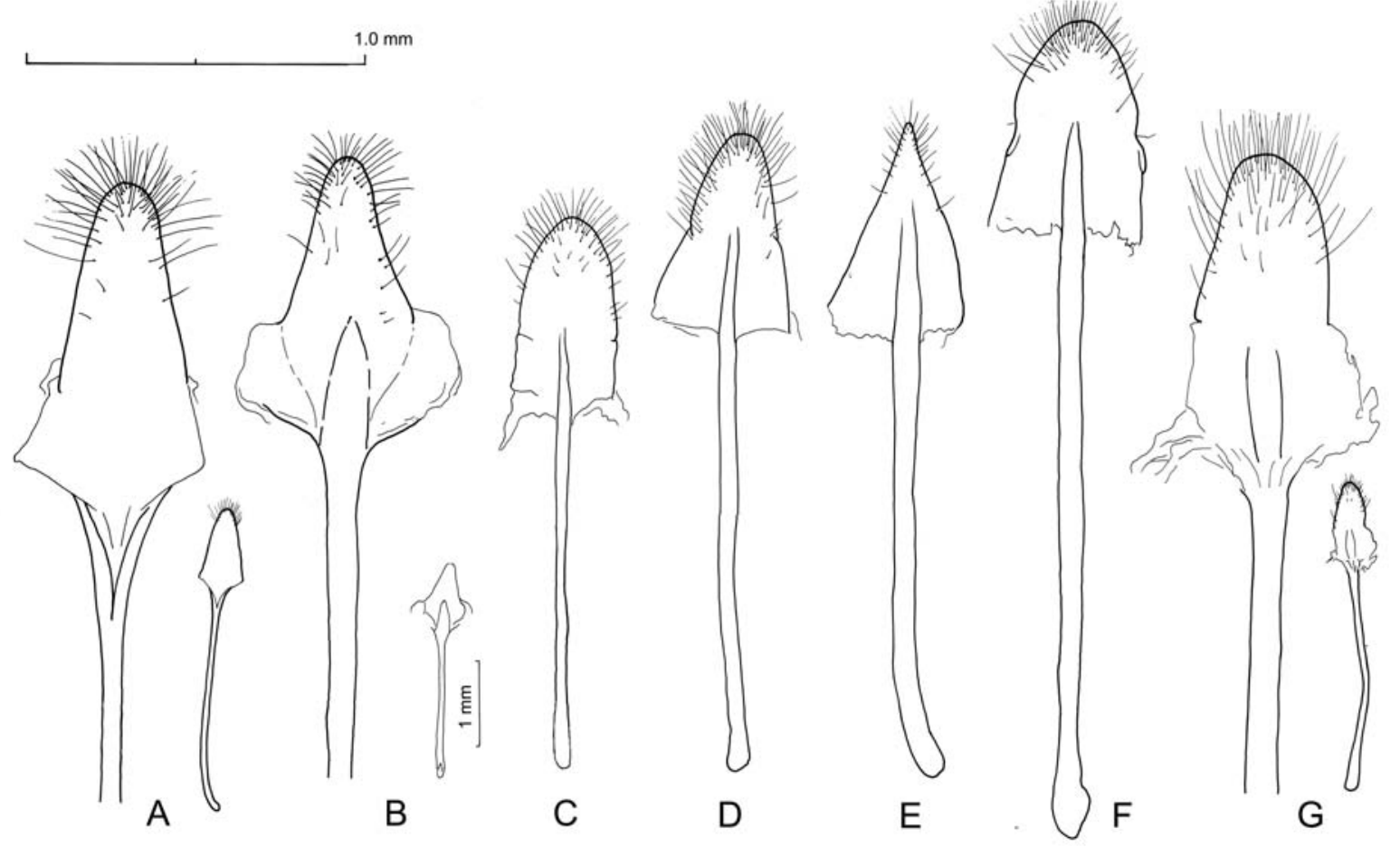

Fig. 8.- Female sternite VIII: A = L. (Laparocerus) cryptus $\mathbf{n} . \mathbf{s p} ., \mathrm{B}=$ L. (Atlantis) madeirensis $\mathbf{n} . \mathbf{s p}$. , $\mathrm{C}=$ L. (Pseudatlantis) silvaticus n. sp., $\mathrm{D}=$ L. (Pseudatlantis) stuebeni $\mathbf{n} . \mathbf{s p} ., \mathrm{E}=$ L. (Atlantis) serrado $\mathbf{n} . \mathbf{s p} ., \mathrm{F}=$ L. (Atlantodes) prainha $\mathbf{n} . \mathbf{s p}$., and $\mathrm{G}=$ L. (Atlantis) hobbit $\mathbf{n}$. sp.

Fig. 8. - Esternito femenino VIII: A = L. (Laparocerus) cryptus n. sp., B = L. (Atlantis) madeirensis $\mathbf{n} . \mathbf{s p} ., \mathrm{C}=$ L. (Pseudatlantis) silvaticus $\mathbf{n} . \mathbf{s p} ., \mathrm{D}=$ L. (Pseudatlantis) stuebeni $\mathbf{n} . \mathbf{s p .}, \mathrm{E}=$ L. (Atlantis) serrado $\mathbf{n} . \mathbf{s p . ,} \mathrm{F}=$ L. (Atlantodes) prainha $\mathbf{n} . \mathbf{s p .}$, and $\mathrm{G}=$ L. (Atlantis) hobbit $\mathbf{n}$. sp.

ETYMology. The specific name is a Latin adjective meaning wild, derived from silva $=$ forest, used here in reference to the habitat of the species.

Distribution AND ECOLOGY. Laparocerus silvaticus lives in the moist laurel-forests of the windward part of Madeira, at lofty elevations (800-1350 $\mathrm{m})$. It is common in summer at night and apparently very polyphagous, having been beaten from many different plant species of the forest undergrowth (Plantago, Geranium, Juncus, Hypericum, etc.) as well as from taller bushes like Vaccinium or Erica (Ericaceae). In contrast, L. abditus seems to be restricted to lower altitudes in the dryer leeside of the island, inhabiting scrub vegetation with Euphorbia piscatoria (Euphorbiaceae) or Globularia salicina (Globulariaceae).

REMARKS. This new species is probably the Laparocerus excelsus var. $ß$ of Wollaston (1854). It is related to L. abditus (see fig. 1) and L. stuebeni n. sp. which have much less stout elytra (seen in profile), have apically incurved protibia with mucro, and bear noticeably longer pilosity all over, plus a differently shaped aedeagus and female tergite VIII. In addition, males and females of $L$. abditus and L. stuebeni $\mathrm{n}$. sp. are clearly distinct in outline. Other Pseudatlantis species have almost no marked pilosity on the elytra (L. excelsus), or just a few isolated erect setae on posterior half ( $L$. schaumii).

\section{Laparocerus (Pseudatlantis) stuebeni n. sp.}

(figs. 7A, 8D, 9F, and $12 \mathrm{~A}-\mathrm{B}$ )

Material eXamined. Holotype: Madeira: $8 \mathrm{~km}$ NW Calheta, Faja da Ovelha (UTM 28S 02905553628279$) 400 \mathrm{~m}, 1 \mathrm{O}^{7} 23-$ 3-2008, leg. Stüben \& Astrin (TFMC, reg. CO-15604). Paratypes: same locality and data $4 \operatorname{exx}(\mathrm{PS})$; same locality 60 exx leg. A. Machado (54 AMC, 2 MNHN, 2 ZMUH, 2 NHM), $10^{7}, 19$ (AMC), 41 exx leg. A. Aguiar (AAC). 


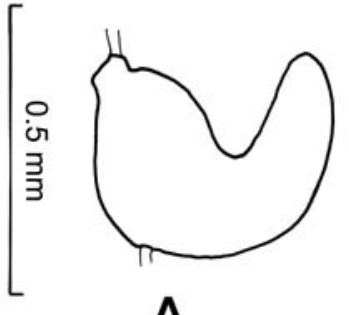

A

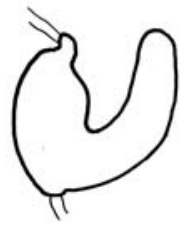

D

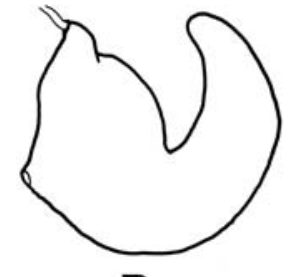

B

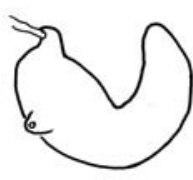

E

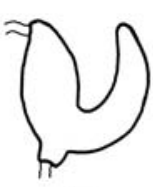

$\mathbf{F}$
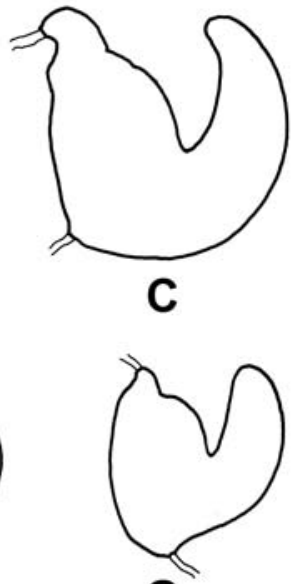

G
Fig. 9. - Spermatheca: $\mathrm{A}=$ L. (Laparocerus) cryptus n. sp., $\mathrm{B}=L$. (Atlantis) madeirensis n. sp., $\mathrm{C}=L$. (Atlantis) hobbit $\mathbf{n}$. sp., $\mathrm{D}=$ L. (Atlantis) serrado $\mathbf{n}$. sp., $\mathrm{E}=L$. (Pseudatlantis) silvaticus $\mathbf{n} . \mathbf{s p} ., \mathrm{F}$ $=L$. (Pseudatlantis) stuebeni $\mathbf{n}$. sp., and $\mathrm{G}=$ L. (Atlantodes) prainha $\mathbf{n} . \mathbf{s p}$.

Fig. 9. - Espermateca: $\mathrm{A}=$ L. (Laparocerus) cryptus n. sp., $\mathrm{B}=L$. (Atlantis) madeirensis n. sp., $\mathrm{C}=L$. (Atlantis) hobbit $\mathbf{n}$. sp., $\mathrm{D}=L$. (Atlantis) serrado $\mathbf{n}$. sp., $\mathrm{E}=L$. (Pseudatlantis) silvaticus $\mathbf{n}$. sp., $\mathrm{F}=$ L. (Pseudatlantis) stuebeni $\mathbf{n}$. sp. y $\mathrm{G}=$ L. (Atlantodes) prainha $\mathbf{n}$. sp.
Dimensions, holotype $\left(\sigma^{7}\right)$. Length: total (without rostrum) $5.50 \mathrm{~mm}$, head $1.10 \mathrm{~mm}$, rostrum $0.50 \mathrm{~mm}$, eyes $0.34 \mathrm{~mm}$, scape $1.26 \mathrm{~mm}$, funicle $1.46 \mathrm{~mm}$, articles $\left(1^{\text {st }} / 2^{\text {nd }} / 3^{\text {rd }} / 4^{\text {th }}\right) 0.34$ $/ 0.28 / 0.19 / 0.15 \mathrm{~mm}$, club $0.52 \mathrm{~mm}$, pronotum $1.20 \mathrm{~mm}$, elytra $3.95 \mathrm{~mm}$, and tibiae (pro- /meso/meta-) $1.44 / 1.32 / 1.50 \mathrm{~mm}$. Width: head (with eyes) $0.93 \mathrm{~mm}$, head (between eyes) $0.48 \mathrm{~mm}$, rostrum (with pterygia) $0.72 \mathrm{~mm}$, rostrum (minimum dorsal /ventral) $0.39 / 0.62 \mathrm{~mm}$, eyes 0.26 $\mathrm{mm}$, scape (apicad) $0.16 \mathrm{~mm}$, club $0.18 \mathrm{~mm}$, pronotum (anterior /maximum /posterior) 1.10 $/ 1.57 / 1.25 \mathrm{~mm}$, and elytra (maximum) $2.20 \mathrm{~mm}$. Height: abdomen $1.70 \mathrm{~mm}$.
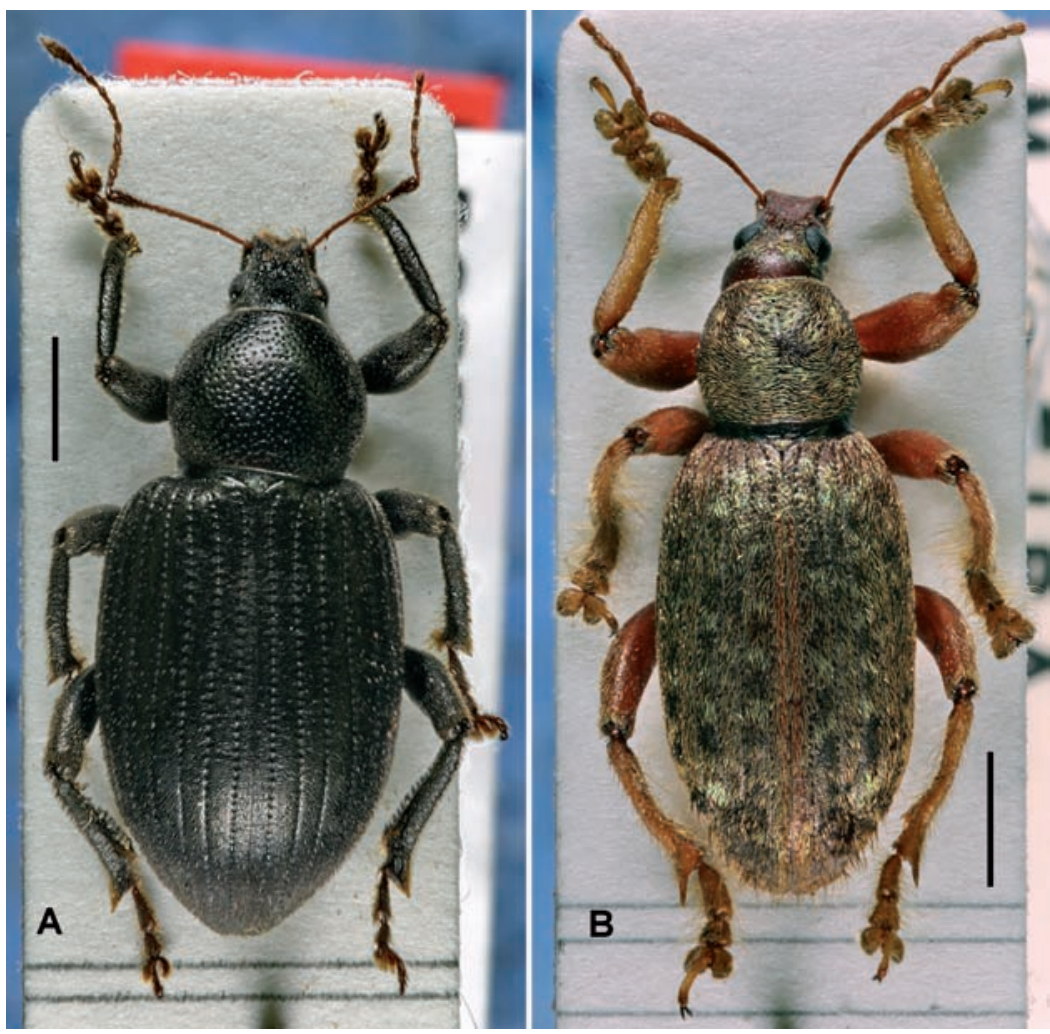

Fig. 10.- Holotypus: A = Laparocerus (Laparocerus) cryptus n. sp., and B = Laparocerus (Atlantis) hobbit n. sp. Scale $2 \mathrm{~mm}$.

Fig. 10.- Holotipos: A = Laparocerus (Laparocerus) cryptus n. sp. y $\mathrm{B}=$ Laparocerus (Atlantis) hobbit n. sp. Escala $2 \mathrm{~mm}$. 
Fig. 11.- Holotypus: A = Laparocerus (Atlantis) madeirensis n. sp., and $\mathrm{B}=$ Laparocerus (Atlantis) serrado n. sp. Scale $2 \mathrm{~mm}$.

Fig. 11.- Holotipos: A = Laparocerus (Atlantis) madeirensis n. sp. y $\mathrm{B}=$ Laparocerus (Atlantis) serrado $\mathbf{n} . \mathbf{s p}$. Escala $2 \mathrm{~mm}$.

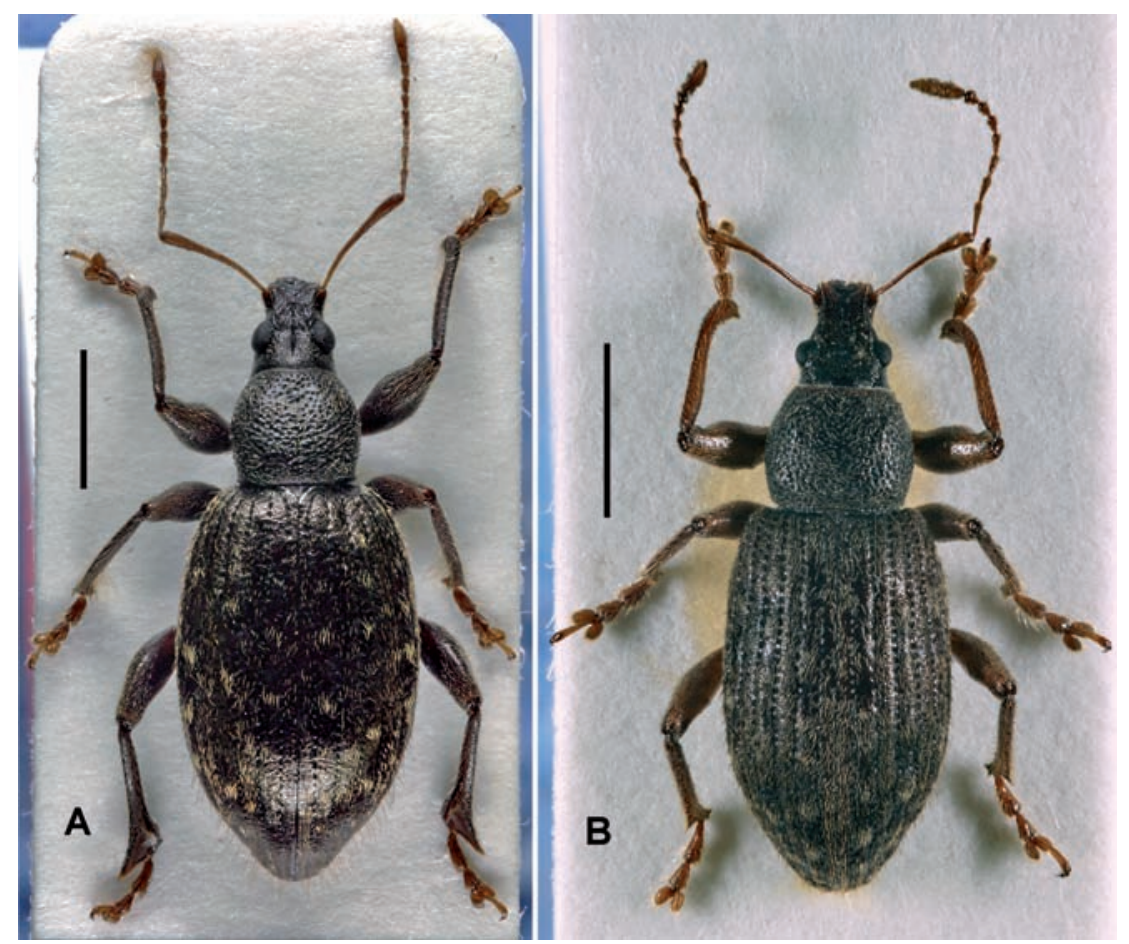

DiAgnosis. Size $0^{\top} \sigma^{\top}=5.5-5.7 \mathrm{~mm}$, 우 우 = 5.4-6.2 $\mathrm{mm}$. Similar to Laparocerus abditus, but body strikingly narrow and elongate (elytra $\mathrm{L} / \mathrm{W}=1.7-1.9 \mathrm{x}$ instead of 1.5-1.6x), especially in males. Integuments less shiny, alutaceous; pilosity long, as well developed as in L. abditus (except on tibiae). Rostrum slightly more constricted dorsally. Pronotum somewhat more robust; punctures less marked; isodiametric microreticulation more developed on interspaces. Male elytra very narrow, elongate-acuminate, with sides less curved (1.4x wider than pronotum, instead of $1.7 x$ ); intervals less convex; punctures of striae smaller and less incised. Male protibiae similarly incurved apicad, but mucro tiny, less developed (mesomucro, the same). Median lobe of aedeagus very flat and much broader, with very short internal sac; at apex differently shaped (fig. 7A). Females wider than males; elytra more curved laterally $(\mathrm{L} / \mathrm{W}$ $=1.6 \mathrm{x})$, but not of broadly rounded outline as in other Pseudatlantis (L/W = 1.8x in L. abditus and L. excelsus, $1.9 \mathrm{x}$ in L. silvaticus). In this species males and females are notably different in outline and foreleg configuration (fig. 13).

Etymology. The species is named after Dr Peter Stüben (Curci-Institut, Mönchengladbach), a good friend and one of the collectors who discovered it in a recent campaign to Madeira (March 2008).
DiSTRIBUTION AND ECOLOGY. Laparocerus stuebeni was found in the south-west end of the island of Madeira (400 m altitude), by shifting debris under a fig tree. The natural habitat of the zone is similar to that inhabited by L. abditus in the eastern part of the island, a dry-scrub vegetation characterised by Euphorbia piscatoria (Euphorbiaceae).

REMARKS. This new species is probably closest related to L. abditus, sharing its long and well developed pilosity, incurved mucronate protibiae, and less stout elytra in profile (in comparison with other species of Pseudatlantis). Peculiar to it is the striking elongate-acuminate outline, particularly of males.

\section{Laparocerus (Atlantodes) prainha $\mathbf{n} . \mathbf{s p}$.}

(figs. 6C, 8F, 9G, and 12B)

Material examined. Holotype: Madeira: Prainha, $30 \mathrm{~m}$. (UTM 28S 0339193 3624189), $10^{\top}$ 22-2-2004, leg. A. Machado (TFMC, reg. CO-15603). Paratypes: 15 exx, same locality and data leg A. Machado (AMC), 13 exx leg. A. Aguiar (AAC); Ponta de São Lourenço, 75 m. (28S 034639 3624090). 6 exx. 22-2-2004, leg. A. Machado (AMC), 2 exx leg. A. Aguiar (AAC). Ponta de São Lourenço: ca. Prainha. 2 exx. 2212-1986, leg. Grimm \& Rachinsky (DEI).

Non Paratypes: Caniçal. 2 exx. 4-12-1986, leg. Grimm \& Rachinsky (1 SMNS, 1 DEI); 1 ex. 22-10-1997, leg. H. Ziegler. (MNCN), 2 exx. 11-2-1987, leg. Th. Heijerman. Coll. Teunissen. Pico do Arieiro [locality error?] 1 exx. 1-1982, leg. 

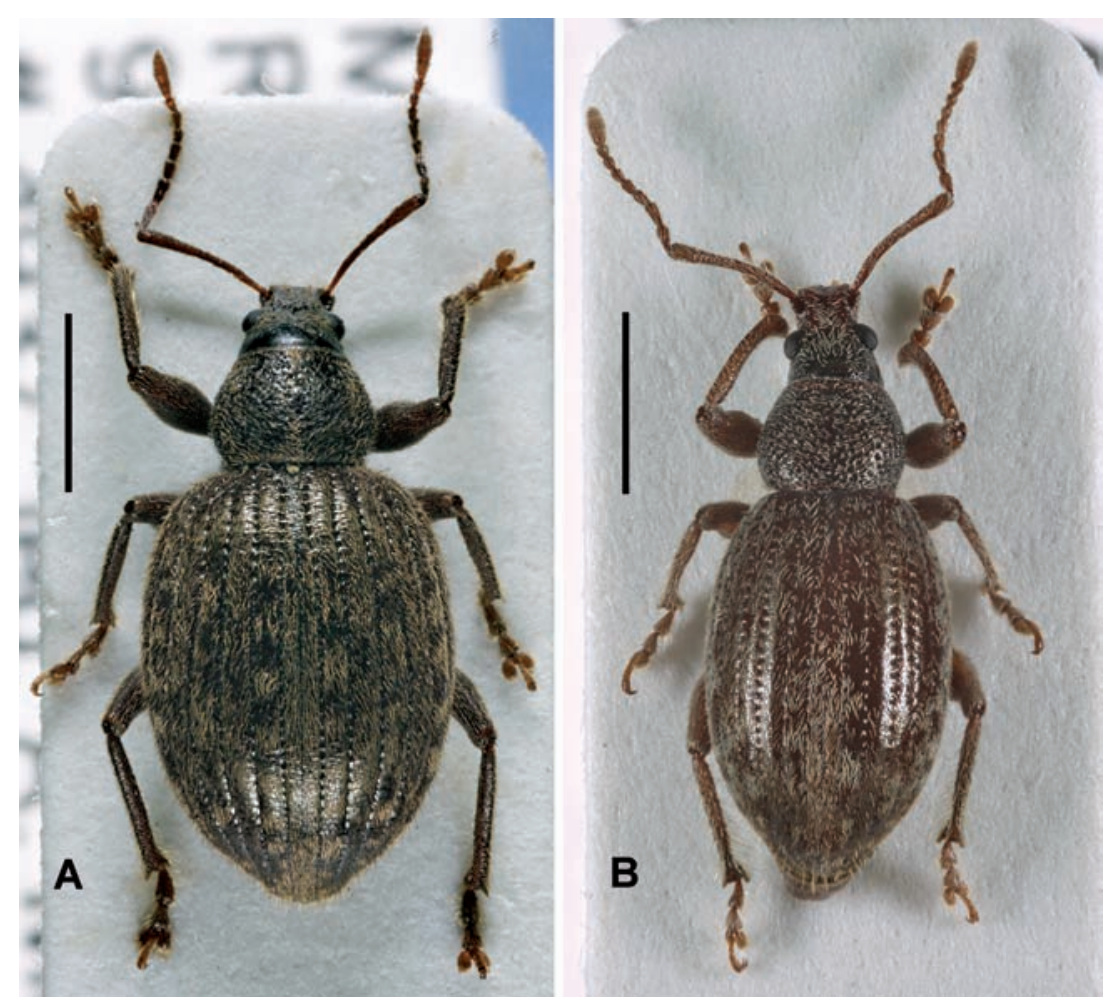

Fig. 12.- Holotypus: $\mathrm{A}=$ Laparocerus (Pseudatlantis) silvaticus $\mathbf{n} . \mathbf{s p}$., and B = Laparocerus (Atlantodes) prainha $\mathbf{n}$. sp. Scale $2 \mathrm{~mm}$.

Fig. 12.- Holotipos: A = Laparocerus (Pseudatlantis) silvaticus n. sp. y $\mathrm{B}=$ Laparocerus (Atlantodes) prainha $\mathbf{n}$. sp. Escala $2 \mathrm{~mm}$.
P. Schurmann. Coll. Magnano; Santo da Serra [locality error?] 2 exx. 21-4-1957, leg. J. Mateu. (MNCN).

DNA sequences. GenBank accession numbers: EF583330 (COII) and EF583403 (16S rRNA) from Prainha, Madeira.

Dimensions, holotype $\left(\sigma^{7}\right)$. Length: total (without rostrum) $5.60 \mathrm{~mm}$, head $1.02 \mathrm{~mm}$, rostrum 0.50 $\mathrm{mm}$, eyes $0.33 \mathrm{~mm}$, scape $1.36 \mathrm{~mm}$, funicle 1.40 $\mathrm{mm}$, articles $\left(1^{\mathrm{st}} / 2^{\text {nd}} / 3^{\text {rd }} / 4^{\text {th }}\right) 0.28 / 0.32 / 0.20 / 0.16$ $\mathrm{mm}$, club $0.46 \mathrm{~mm}$, pronotum $1.14 \mathrm{~mm}$, elytra 3.75 $\mathrm{mm}$, and tibiae (pro- /meso- /meta-) $1.14 / 1.02 / 1.28$ $\mathrm{mm}$. Width: head (with eyes) $0.94 \mathrm{~mm}$, head (between eyes) $0.49 \mathrm{~mm}$, rostrum (with pterygia) $0.71 \mathrm{~mm}$, rostrum (minimum dorsal /ventral) 0.58 / $0.42 \mathrm{~mm}$, eyes $0.25 \mathrm{~mm}$, scape (apicad) $0.18 \mathrm{~mm}$, club $0.18 \mathrm{~mm}$, pronotum (anterior /maximum /posterior) $1.02 / 1.45 / 1.28 \mathrm{~mm}$, and elytra (maximum) $2.50 \mathrm{~mm}$. Height: abdomen $1.42 \mathrm{~mm}$.

Diagnosis. Size $\sigma^{7} \sigma^{\pi}=4.9-6.7 \mathrm{~mm}$, $ᄋ$ Q $=5.0$ $7.0 \mathrm{~mm}$. Similar to L. instabilis but integument more shiny; eyes less prominent, more uniformly rounded (convexity $39-41 \%$ instead of $45-48 \%$ ); first segment of funicle shorter than second (same as L. instabilis); pronotum more rounded laterally at base, with coalescent and deeper puncturation (verrucose) in males; female elytra ovate (not sub-quadrangular) with flat intervals and smaller punctures on striae; elytra with less dense cover of linear scales; chequered design less marked or absent; colouration variable (cinereous, testaceous, with copperish glimmer, etc.); protruding whitish setae small and sparse over entire surface, visible at shoulders (only in apical third in L. instabilis). Venter and femora without long outstanding hairs (very conspicuous in $L$. mendax). Tibiae simple, mucronated; protibiae with outer angle slightly marked (not rounded). Aedeagus with broad point slightly constricted preapically (in dorsal view).

Eтymology. The specific epithet is the name of the type locality Prainha in apposition, which means "little beach" in Portuguese (the insect has preference for sandy soils).

DiSTRIBUTION AND ECOLOGY. Laparocerus prainha n. sp. is endemic to Madeira. It lives on sandy or mixed sandy-clayish soils in the semiarid Ponta de São Lourenço, feeding on low plants like Lotus glaucus (Leguminosae), but also on ruderals (e.g. Solanum nigrum). There are a few specimens apparently obtained from higher altitudes (Pico do Arieiro and Santo da Serra) but these could well be labelling errors. Its sister species $L$. mendax lives preferably on sandy soils, in Porto Santo, while L. instabilis selects clayish soils. 
Fig. 13.- Laparocerus (Pseudatlantis) stuebeni n. sp., $\mathrm{A}=$ holotypus $\left(O^{7}\right)$, and $\mathrm{B}=$ paratypes ( ) ). Scale $2 \mathrm{~mm}$.

Fig. 13.- Laparocerus (Pseudatlantis) stuebeni n. sp., $\mathrm{A}=$ holotipo $\left(\sigma^{7}\right)$ y $\mathrm{B}=$ paratipo ( $ᄋ$ ). Escala $2 \mathrm{~mm}$.

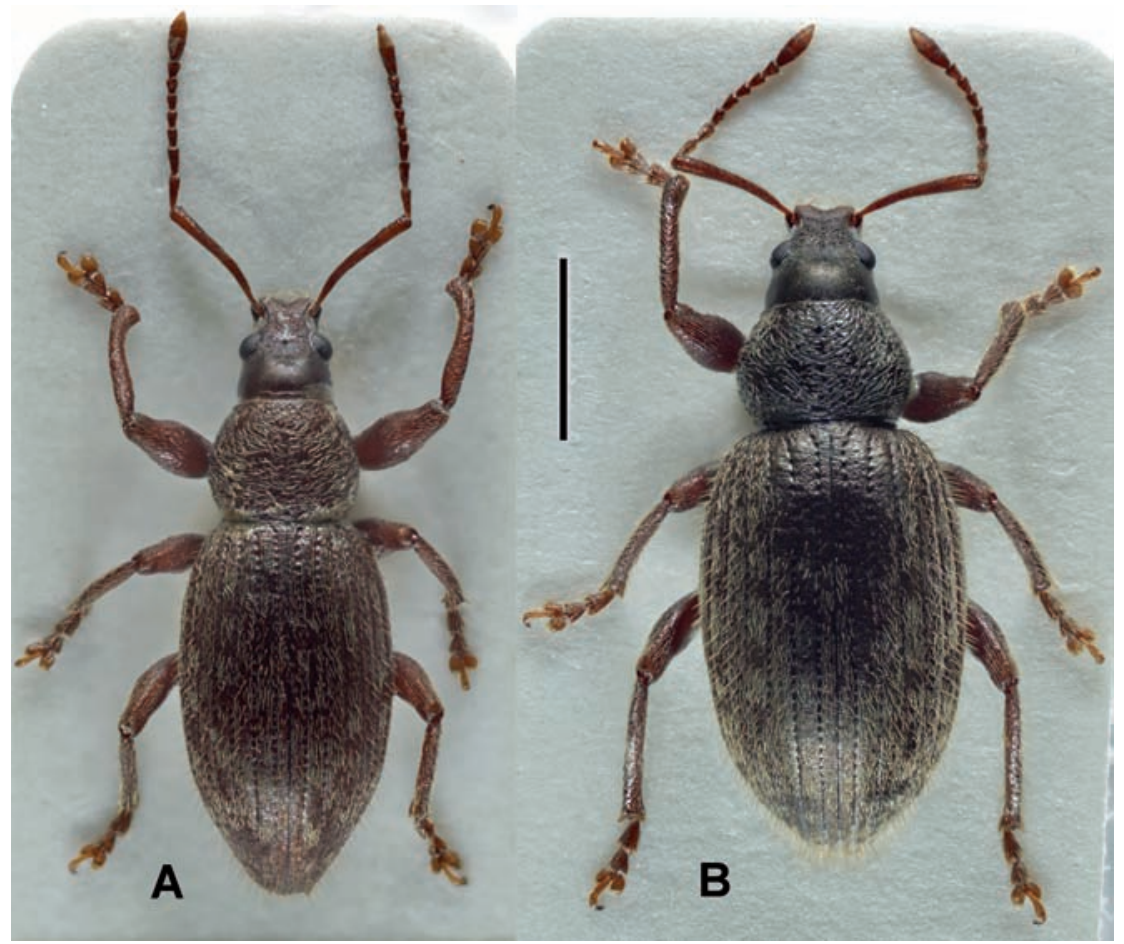

REMARKS. Laparocerus prainha n. sp. represents in Madeira the phyletic line of $L$. mendax - $L$. instabilis from Porto Santo. Because of its moderate size, heavily punctured pronotum and reduced pilosity, it resembles more closely L. instabilis, but DNA sequences (fig. 1) reveal a closer relationship with $L$. mendax. In all three species, the aedeagus is similarly shaped with an abrupt declivity at the apex of the median lobe in lateral view (fig. 6C), but differs in its shape in dorsal view: it is uniformly tapering in $L$. mendax, preapically swollen in $L$. instabilis, and shortly constricted in L prainha $\mathrm{n}$. $\mathrm{sp}$. The general pilosity is much more developed in L. mendax, including antennae, dorsum, venter and legs, the first and second segments of funicle are equal, and the puncturation of the pronotum is finer and less dense (smooth surface in between clearly visible).

\section{Key to the species of Laparocerus from Madeira,} Porto Santo and the Desertas.

1 Integument bare or more or less densely beset with longitudinal scales. Eyes in lateral view near or reaching frons level. Scape slender

- Integument fully covered with short drop-like scales. Eyes tiny, in lateral view placed at mid-face, distant from frons level. Scape strongly incrassate (subg. Lichenophagus) .. 33
2 Scape capitate (apically swollen for $1 / 4-1 / 5^{\text {th }}$ of its length), usually straight or sinuous

3

- Scape clavate (progressively and smoothly widening towards apex), usually arcuate ..................................... 15

3 Size $<5 \mathrm{~mm}$. Male protibiae never incurved apically (subg. Wollastonius) ............................................................... 4

- Size $>5 \mathrm{~mm}$. Male protibia clearly incurved apically ..7

4 Pronotum conical, broadest at base; integument smooth, with shallow micro-punctures. Elytra bare, with some patches of few apressed scales (Madeira, Deserta Grande)

L. (Wollastonius) waterhousei (Wollaston, 1854)

- Pronotum broadest at or near middle; integument strongly and coarsely punctured. Elytra uniformly clothed with scales, with or without protruding setae or hairs 5

5 Integument glossy with golden sheen. Elytra with abundant long hairs throughout (Madeira)

L. (Wollastonius) aenescens (Wollaston, 1854)

- Integument nitid-alutaceous, without golden sheen. Elytra with short curved (backward-pointing) protruding setae .. 6

6 Elytra elongate-subparallel (L/W > 1.37), base concave, setae short and scarcely protruding in apical half (Madeira)

L. (Wollastonius) angustulus (Wollaston, 1854)

- Elytra shorter $(\mathrm{L} / \mathrm{W}<1.37)$, with rounded sides; base straighter, setae clearly protruding throughout, longer and more conspicuous (Madeira)

L. (Wollastonius) ventrosus (Wollaston, 1854)

7 Rostrum dorsally not constricted, sides subparallel; epistomal keel complete and strongly developed (subg. Laparocerus) 
- Rostrum dorsally constricted before the level of insertion of antennae; epistomal keel obsolete or poorly marked (subg. Atlantis, pars) 12

8 Elytra widest at basal third; shoulders markedly protruding forwards. Male metatibiae strongly expanded, widest near middle (Madeira)

L. (Laparocerus) distortus (Wollaston, 1854)

- Elytra widest at or near middle; shoulders rounded and not projecting forwards. Male metatibiae less expanded, widest pre-apically ... 9

9 Male metatibiae with posterior apical lobe more abruptly protruding; articular smooth area broadly triangular (figs. 3P-Q). Aedeagus with two rows of more than 30 teeth at base of internal sac.

10

- Male metatibiae with posterior apical lobe not or slightly protruding; articular smooth area trapezoidal or quadrangular (usually longer than broader) (fig. $3 \mathrm{~N}-\mathrm{O}$ ). Aedeagus with two rows of 9-13 teeth at base of internal sac ...... 11

10 Male metatibiae with large internal apical notch $(>1 / 3$ length of apical rim, fig. 3P). Internal sac of aedeagus with two rows of 30-31 teeth at base (Ilheu de Chão and Bugio)

L. (Laparocerus) chaoensis chaoensis Uyttenboogaart, 1940

- Male metatibiae with extremely short internal apical notch $(<1 / 3$ length of apical rim, fig. 3Q). Internal sac of aedeagus with two rows of 50-70 teeth at base (Ilheu da Cevada) ....... L. (Laparocerus) chaoensis cevadae Roudier, 1961

11 Appressed linear scales of elytra shorter, hardly overlapping. Crenulation of internal margin of male metatibia stronger; outer apical margin almost straight; articular smooth area more elongate (fig. 30). Males and females less different in width (Porto Santo, Deserta Grande, and Ponta de São Lourenço) ........................... L. (Laparocerus) cryptus n. sp

- Appressed linear scales of elytra longer, overlapping. Crenulation of internal margin of male metatibia less developed; outer apical margin slightly protruding; articular smooth area more trapezoidal (fig. 3N). Males clearly narrower than females (Madeira, except Ponta de São Lourenço and islets)

L. (Laparocerus) morio Boheman, 1834

12 First metatarsal article with asymmetric base. Male metatibiae with preapical combs of very long hairs ............. 13

- First metatarsal article symmetrically tapering towards base. Male metatibiae with normal pilosity (no special combs) 14

13 Pronotum with separate large deep punctures. Elytra with undulating uneven intervals. Male metatibiae pre-apically notched (Madeira)

L. (Atlantis) undulatus (Wollaston, 1854)

- Pronotum with coalescent punctures of strong variolose appearance. Elytral intervals without undulations. Male metatibiae not notched (Madeira)

L. (Atlantis) lindbergi Roudier, 1963

14 Pronotum notably much broader at base than apex. Elytral shoulders strongly projecting forwards (porrect). Male proand mesotibiae each with strong mucro (Madeira)

L. (Atlantis) clavatus (Wollaston, 1854)

- Pronotum less broad at base, sides more uniformly and strongly curved. Elytral shoulders not or slightly projecting forwards. Male pro- and mesotibiae with tiny mucro (Madeira)

L. (Atlantis) serrado n. sp.

15 Male metatibiae with apical posterior projecting lobe; tarsal articular area smooth and notably extended along inner face of tibia. Elytra always with long erect hairs (approx. as long as first metatarsal segment) (subgen. Atlantis, pars) .. 16

- Metatibiae of males simple, not particularly expanded at apex. Elytra with or without long hairs ........................ 22

16 Elytra bearing tufts of strong black setae (single setae in some females) in addition to the longer testaceous hairs ............17

- Elytra with normal long pilosity, without additional tufts of strong black setae 18

17 Second tarsal segment elongate; first and second segment of antennal funicle of equal length

L. (Atlantis) lamellipes (Wollaston, 1854)

- Second tarsal segment strongly transverse; first segment of antennal funicle shorter than second

L. (Atlantis) hobbit n. sp.

18 Pronotum dull in contrast with the elytra. Elytra elliptical, with pilosity clearly much longer in apical third (anterior apical process of male metatibiae less protruding, almost running parallel and shortly truncated apically)

L. (Atlantis) madeirensis n. sp.

- Pronotum as shiny as elytra. Elytra oblong, with more uniform pilosity. Anterior apical process of male metatibiae differently shaped or absent 19

19 Pronotum widest at middle; sides uniformly rounded. Male metatibiae progressively expanded apicad (cuneiform), only with upper process, which is less salient than first metatarsal segment (Madeira)

L. (Atlantis) vespertinus (Wollaston, 1854)

- Pronotum widest after middle, sides more straight near anterior margin. Male metatibiae abruptly and strongly expanded apically, with long posterior process and short anterior process or heel ............................................... 20

20 Elytra clearly widest behind middle; male metatibiae with posterior process longer and more acute (about $30^{\circ}$ ), its anterior process or heel strongly protruding and beak-like; femora strongly incrassate (Madeira)

L. (Atlantis) calcatrix (Wollaston, 1854)

- Elytra widest at middle; male metatibiae with posterior process shorter and less acute $\left(>40^{\circ}\right)$; femora not especially incrassate .. 21

21 Anterior process or heel of male metatibiae acute. Elytra with more sparse and robust pilosity (Madeira)

L. (Atlantis) noctivagans (Wollaston, 1854)

- Anterior process or heel of male metatibiae rounded, hump-like shaped. Elytra more densely and softly pilose (Madeira) .... L. (Atlantis) lauripotens (Wollaston, 1854)

22 Elytra with rounded-off anterior angles (effaced shoulders), usually stout, and of rounded appearance (except $L$. stuebeni). Clavate scape feebly and uniformly arcuate (subgen. Pseudatlantis) .............................................. 23

- Elytra clearly truncate at base (marked angles), appearance elongate and never stout. Clavate scape clearly curved in basal third or half (subgen. Atlantodes) 29 
23 Elytra devoid of conspicuous erect setae or hairs (tiny recumbent setae hardly protruding in apical half) (Madeira)

L. (Pseudatlantis) excelsus (Wollaston, 1854)

- Elytra with noticeable erect protruding setae or hairs.....24

24 Protruding stiff setae isolated and restricted to posterior half of elytra (Madeira, Porto Santo, Ilheu de Fora, Ilheu da Cevada) .. L. (Pseudatlantis) schaumii (Wollaston, 1854)

- Elytra and pronotum with uniform vestiture of protruding bent setae 25

25 Male protibiae almost straight at apex, without mucro; elytra stout (see in profile) with short pubescence (Madeira, windward side) ......... L. (Pseudatlantis) silvaticus $\mathrm{n}$. $\mathrm{sp}$.

- Male protibiae shortly incurved at apex, with mucro; elytra not stout and with 1.5-2.0x longer pubescence ............ 26

26 Elytra with broad-ovate outline, clearly broader than pronotum, in males $1.7 \mathrm{x}$ (Madeira)

L. (Pseudatlantis) abditus Roudier, 1963

- Elytra with oblong-elongate outline, slightly broader than pronotum, in males 1.3x (Madeira)

L. (Pseudatlantis) stuebeni n. sp.

27 Anterior femora with long protruding hairs; protibiae very

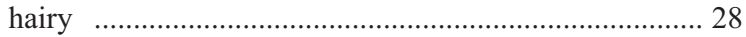

- Anterior femora without long protruding hairs; protibia with normal pilosity

31

28 Elytra and pronotum with erect setae or hairs over the entire surface

- Erect setae restricted to apical third of elytra 30
29 Elytra with abundant long erect silken hairs (as long as or longer than onychium). Protibiae with external apical angle rounded (Madeira)

L. (Atlantodes) lanatus (Wollaston, 1854)

- Elytra with decumbent setae, shorter than onychium. Protibiae with external apical angle briefly salient (Porto Santo)

L. (Atlantodes) mendax (Wollaston, 1854)

30 Scape more robust, widening from near the base (Madeira) L. (Atlantodes) colasi Roudier, 1958.

- Scape slender at base, widening from near middle (Porto Santo) ...... L. (Atlantodes) navicularis (Wollaston, 1854).

31 Rostrum with small, less salient pterygia. Eyes elongate, with convexity $<35 \%$. (Porto Santo)

L. (Atlantodes) inconstans (Wollaston, 1854)

- Rostrum with large outstanding pterygia. Eyes globose, with convexity $>38 \%$

32

32 Elytra with few erect setae only at apex. Eyes more outstanding. Pronotum less rounded laterally at base (Porto Santo) .......... L. (Atlantodes) instabilis (Wollaston, 1854)

- Elytra with small erect whitish setae, including on shoulders. Eyes less convex. Pronotum more rounded laterally at base (Madeira: Ponta de São Lourenço)

L. (Atlantodes) prainha n. sp.

33 Insect with ovate outline. Elytra with erect setae hardly noticeable (Porto Santo)

L. (Lichenophagus) fritillus (Wollaston, 1854)

- Insect with oblong-parallel outline. Elytra with conspicuous erect hairs (Deserta Grande)

L. (Lichenophagus) acuminatus (Wollaston, 1854)

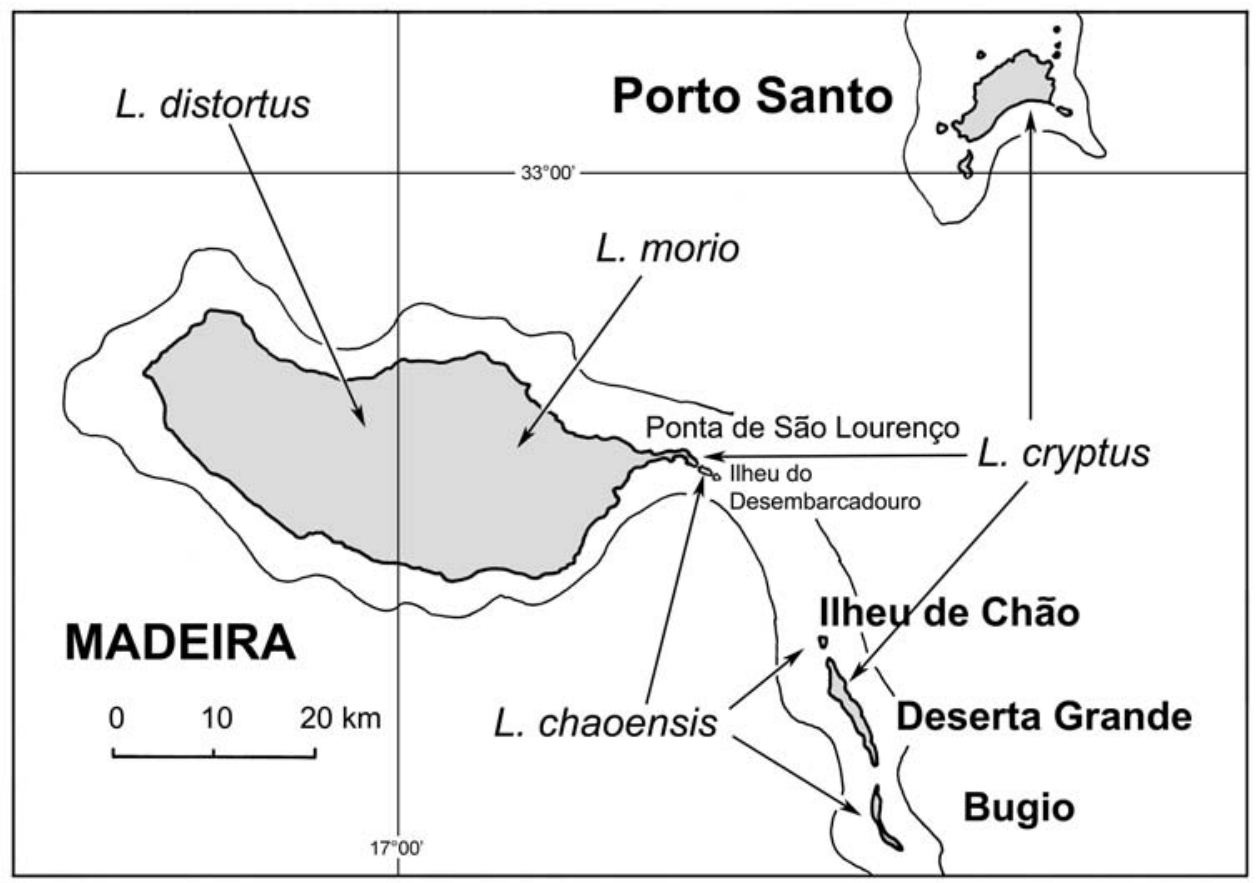

Fig. 14.- Distribution of Laparocerus species (subgenus Laparocerus) in the Madeiran archipelago.

Fig. 14.- Distribución de las especies de Laparocerus (subgénero Laparocerus) en el archipiélago de Madeira. 


\section{ACKNOWLEDGEMENTS}

This study has benefited from partial financial support of the Fundación Biodiversidad (Madrid) and from the comments of Dr Analía Lanteri (La Plata), Dr Richard T. Thompson and Dr Miguel Ángel Alonso-Zarazaga (Madrid). The author wishes to express his appreciation to all curators and colleagues who provided specimens for the present study. Dr Michael Morris kindly revised the English text.

\section{References}

Boheman, C. H., 1834. See Schönherr (1834)

Caterino, M. S., Cho, S. \& Sperling, A. H., 2000. The current state of insect molecular systematics: a thriving tower of Babel. Annual Review of Entomology, 45: 1-54.

Cook, L. M., Cameron, R. A. D. \& Lace, L. A., 1990. Land snails of eastern Madeira: speciation, persistence and colonization. Proceedings of the Royal Society of London, Series B, 239: 83-103.

Damoiseau, R., 1967. Monographie des Coléoptères Brentidae du Continent Africain. Annales du Musée Royal de l'Afrique Centrale, Série in-8, Sciences Zoologiques, 1: 1-507.

LACORDAIRE, T., 1863. Histoire naturelle des Insectes. Genera des Coléoptères. T. VI. Curculionides. Librairie Encyclopédique de Roret. Paris. 594 p.

Machado, A., 2006. The type material of the species of Laparocerus Schönherr, 1834 (Coleoptera, Curculionidae, Entiminae). Journal of Natural History, 40(35-37): 2001-2055.

Machado, A., López, M., Almeida, T. \& Hernández, M., 2008. Molecular phylogeny of the genus Laparocerus Schönherr, 1834 (Coleoptera, Curculionidae, Entiminae). I. The Madeiran clade. Zoologica scripta, 37: 415-427. DOI:10.1111/j.1463-6409.2008.00331.x

Roudier, A., 1957. Curculionides nouveaux ou peu connus des îles Canaries (Col.). Annales de la Société entomologique de France, [1956], 125: 17-55.

Roudier, A., 1958. Curculionides de 1'Archipel de Madère. Revue française d'Entomologie, 25: 199-214.

Roudier, A., 1961. Curculionides de l'Archipel de Madère (Deuxième Note). Revue française d'Entomologie, 28(2): 61-72.

Roudier, A., 1963. XIX. Curculionides de l'Archipel de Madère (Troisième note). In: Lindberg, H. A contribution to the study of beetles in the Madeira Islands. Results of expeditions in 1957 and 1950. Commentationes biologicae, 25(2): 130-153.
SCHÖNHERR, C. J., 1834. Genera et species Curculionidum, cum synonymia hujus familiae. Species novae aut hactenus minus cognitae, descriptionibus a Dom. Leonardo Gyllenhal, C.H. Boheman, et entomologis aliis illustratae. Vol 3(2). Roret. Paris. pp. 329-669.

Thompson, R. T., 1989. Terminology of the spermatheca - a protest. Curculio, 26: 34.

Uyttenboogaart, D. L., 1940. Voyages de M. Ch. Alluaud aux Iles Canaries (1889-90) et à l'archipel de Madère (1938). Coléoptères Curculionides. (Contributions to the knowledge of the fauna of the Canary Islands, XXIV). Revue française d'Entomologie, 7: 49-69.

Uyttenboogaart, D. L., 1947. Coleoptera (ecl. Staphylinidae et Hydrophilidae) von den Azoren und Madeira. Commentationes Biologicae, Helsingfors, 8(12): 1-15.

Wollaston, T. V., 1854. Insecta Maderensia; being an account of the insects of the islands of the Madeiran group. Taylor \& Francis. London. $43+634$ p. (13 pls).

Wollaston, T. V., 1857. Catalogue of the Coleopterous insects of Madeira in the collection of the British Museum. Taylor and Francis. London. 16+ 234 pp.

Wollaston, T. V., 1862. On additions to the Madeiran Coleoptera. Annals and Magazine of Natural History (Ser. 3), 10: 287-293.

Wollaston, T. V., 1871. On additions to the Atlantic Coleoptera. Transactions of the Royal Entomological Society of London, 1871(2): 203-314.
Recibido, 21-X-2008 Aceptado, 25-XI-2008 Publicado, 29-XII-2008 